\title{
Polymers as Encapsulating Agents and Delivery Vehicles of Enzymes
}

\author{
Adejanildo da S. Pereira ${ }^{1}\left(\mathbb{D}\right.$, Camila P. L. Souza $^{1}{ }^{(\mathbb{D}}$, Lidiane Moraes $^{1}$, Gizele C. Fontes-Sant'Ana ${ }^{2}$ \\ and Priscilla F. F. Amaral 1,*iD \\ 1 Escola de Química, Universidade Federal do Rio de Janeiro, Rio de Janeiro 21941-909, Brazil; \\ adejanildosp@gmail.com (A.d.S.P.); camila_lins@hotmail.com.br (C.P.L.S.); lidiane@eq.ufrj.br (L.M.) \\ 2 Biochemical Processes Technology Department, Chemistry Institute, Universidade do Estado do Rio de \\ Janeiro, Rio de Janeiro 20550-013, Brazil; gizele.santana@uerj.br \\ * Correspondence: pamaral@eq.ufrj.br; Tel.: +55-21-3938-7623
}

check for updates

Citation: da S. Pereira, A.; Souza, C.P.L.; Moraes, L.; Fontes-Sant'Ana, G.C.; Amaral, P.F.F. Polymers as Encapsulating Agents and Delivery Vehicles of Enzymes. Polymers 2021, 13, 4061. https://doi.org/10.3390/ polym 13234061

Academic Editor: Dimitrios Bikiaris

Received: 29 October 2021

Accepted: 13 November 2021

Published: 23 November 2021

Publisher's Note: MDPI stays neutral with regard to jurisdictional claims in published maps and institutional affiliations.

Copyright: (c) 2021 by the authors. Licensee MDPI, Basel, Switzerland. This article is an open access article distributed under the terms and conditions of the Creative Commons Attribution (CC BY) license (https:// creativecommons.org/licenses/by/ $4.0 /)$.

\begin{abstract}
Enzymes are versatile biomolecules with broad applications. Since they are biological molecules, they can be easily destabilized when placed in adverse environmental conditions, such as variations in temperature, $\mathrm{pH}$, or ionic strength. In this sense, the use of protective structures, as polymeric capsules, has been an excellent approach to maintain the catalytic stability of enzymes during their application. Thus, in this review, we report the use of polymeric materials as enzyme encapsulation agents, recent technological developments related to this subject, and characterization methodologies and possible applications of the formed bioactive structures. Our search detected that the most explored methods for enzyme encapsulation are ionotropic gelation, spray drying, freezedrying, nanoprecipitation, and electrospinning. $\alpha$-chymotrypsin, lysozyme, and $\beta$-galactosidase were the most used enzymes in encapsulations, with chitosan and sodium alginate being the main polymers. Furthermore, most studies reported high encapsulation efficiency, enzyme activity maintenance, and stability improvement at $\mathrm{pH}$, temperature, and storage. Therefore, the information presented here shows a direction for the development of encapsulation systems capable of stabilizing different enzymes and obtaining better performance during application.
\end{abstract}

Keywords: polymers; encapsulation; enzymes; chitosan; sodium alginate

\section{Introduction}

Enzymes are valuable molecules for several reasons, including mild reaction conditions, biodegradability, selectivity, high yields, and renewability. In this sense, industries are increasingly demanding their use in quite a few products and processes, mainly in the textile, detergent, starch, pharmaceutical, and fuel sectors [1].

The use of agro-industrial wastes [2,3], media optimization [4], and many modern techniques, such as protein engineering [5] and directed evolution [6], has managed to reduce enzyme production costs and provide many interesting new applications. Even so, the immobilization of these biocatalysts is essential for industrial use because of operational stability and reusability [7]. Besides, immobilization is also a crucial technique for the controlled release of these catalytic proteins at specific locations (target site), at a specific rate, or in response to environmental triggers, such as $\mathrm{pH}$, ionic strength, temperature, or enzymatic activity [8]. These features are important for pharmaceutical applications and can improve the technical-functional performance of these molecules [9].

Numerous immobilization techniques have been studied and are still under investigation to obtain robust high activity biocatalysts, and they are divided into three categories: adsorption on a carrier (support), encapsulation in a carrier (entrapment), and crosslinking (carrier-free) [10]. Regardless of the immobilization strategy, polymers certainly play a crucial role in this process: the use of synthetic, natural, inorganic, and smart polymers has been reported so far [10]. 
The entrapment of an enzyme in a polymer network allows substrates and products to pass through while retaining the enzyme; it can also be designed to release the enzyme in a controlled manner at the target site under specific conditions [11]. Usually, the enzyme does not interact with the polymer, reducing problems of active site block which are faced by adsorption techniques frequently used for industrial applications [12]. However, for these uses, a disadvantage would be that physical restrictions do not prevent enzyme leakage. Hence, some strategies to overcome this problem have been proposed, such as the addition of a second polymer [13]. For controlled release, this characteristic is an advantage used for enzyme delivery [14]. In the present review, we will focus on entrapment techniques used to encapsulate enzymes using polymers.

Several enzyme entrapment methods are reported, and they generally involve mixing the enzyme with a monomer solution, followed by polymerization [15]. Ionic gelation [13], spray drying [16], freeze-drying [17], nanoprecipitation [18], and electrospinning [19] are the latest, most used, and efficient methods to encapsulate enzymes.

The most important parameters to evaluate enzyme immobilization are immobilization yield, global enzyme activity yield, expressed activity (recovered activity or activity recovery), and enzyme loading [20]. Physical characterization of those biocatalysts generally involves particle size and density determination, hydrophobicity measurements, and mechanical robustness evaluation [10]. All these parameters and the physical characterization related to the encapsulation of enzymes by polymers will be addressed in the present review.

Despite the numerous reviews related to enzyme immobilization found in the literature [7,10-12], none of them focus on the encapsulation procedures of these molecules. Therefore, in the present review, we aimed at describing polymers as encapsulating agents for enzymes, the recent technological developments related to this subject, and depicting characterization methodologies and possible applications of these bioactive materials.

\section{Polymeric Materials}

Polymers are large molecules consisting of multiple repetitions of one or more units, known as monomers, which react to form polymer chains by the process of polymerization and can present peculiar properties [21]. These large molecules can be classified into three categories according to their source: natural, synthetic, and semi-synthetic, and all of them can be used as encapsulating material for a variety of biomolecules. An ideal material for encapsulation requires good rheological properties, stabilization, non-reactivity with the core material, solubility in non-toxic solvents, non-hygroscopicity, and the possibility of releasing the core material under specific conditions [22].

Natural polymers, or biopolymers, are synthesized from plants, animals, and microorganisms and are mainly composed of proteins (gelatin, collagen, and albumin), polysaccharides (starch, cellulose, agarose, and chitosan), and lipids (paraffin, beeswax, and stearic acid). Biopolymers are largely used in the food and medicine industries due to their non-toxic character, biodegradability, and biocompatibility [23,24].

Although biopolymers generally display unchangeable properties, which may hinder their interaction with various substances, these materials offer a large diversity as matrices and are biodegradable, producing non-toxic by-products. In contrast, they can generate immunogenic reactions and present an uncontrollable rate of degradation [25].

Synthetic polymers are laboratory synthesized molecules, which mainly include polyamide, polyethylene glycol, poly (vinyl acetate), and polyethylene. This type of polymer exhibits easily tailored properties, which enables their adaptation to several applications, and they also display an inert behavior under physiological conditions. Moreover, synthetic polymers present mechanical and chemical stability and good reproducibility [26].

Tunable properties, endless forms, and established structures are some advantages of synthetic polymers over natural ones. On the other hand, some synthetic substances can be harmful to human beings, and are thus avoided by the food and drug industries [27]. 
The semi-synthetic polymer is a combination of a synthetic and a natural substance, or a blend, enhancing the best qualities and diminishing the undesirable characteristics of each material [28].

Considering the polymer chain's backbone type, polymers can also be divided into organic polymers - carbon core-and inorganic polymers, constituted by elements other than carbon. Inorganic polymers are amorphous substances formed by a chain of $\mathrm{SiO}_{4}$ and $\mathrm{AlO}_{4}$ tetrahedra, which share all oxygen atoms. This type of polymer displays good physical and chemical properties, such as high compressive strength, thermal stability, and low permeability [29]. In contrast, organic polymers exhibit a close analogy to the environment predominant in homogeneous polymerization and do not require complex pathways to be produced. Organic-inorganic polymer hybrids can also achieve unique properties once organic compounds are frequently dispersed in an inorganic matrix at a molecular level [30].

Another type of polymeric material is the smart polymer, a stimulus-responsive polymer network that changes its conformation dramatically when slight variations occur in the medium, such as in temperature, $\mathrm{pH}$, or ionic strength [10]. Smart polymers undergo large reversible, physical, or chemical changes and can reverse the transitions. Furthermore, smart polymers can be biocompatible, even though they can be hard to handle and sterilize [31].

Polymers are applied mainly for biomolecule encapsulation and, depending on the chosen material, variable properties can be obtained. Some substances can be more suitable for encapsulating certain molecules than others, and costs, extrinsic and intrinsic factors, and objectives must be considered in this choice. Polysaccharides, vegetable and animal proteins, and gums are common natural encapsulating materials, but synthetic polymers are also used to encapsulate active ingredients [10].

\section{Most Used Polymers for Enzyme Encapsulation}

\subsection{Chitosan}

Chitosan is a natural polycationic linear polysaccharide $((1 \rightarrow 4)$ - $\beta$-linked 2 -amino-2deoxy-D-glucose) derived from chitin. Chitin is an abundant renewable polymer, and chitosan, its deacetylated derivative, is a widely used biopolymer [32]. Shrimps, crabs, and other crustaceans' shells have chitin $(\beta-(1 \rightarrow 4-N$-acetyl-D-glucosamine $)$ in their composition, which can react with alkaline sodium hydroxide, leading to an $N$-deacetylation product, also called chitosan [33].

Electrostatic interactions with molecules containing negatively charged groups are developed as the amino groups of chitosan and its protonation, which generates $\mathrm{NH}^{3+}$, together with its linear chains, react. Furthermore, the presence of this functional group and a hydroxyl on chitosan chains allows for chemical modifications [34].

Chitosan has many advantages for enzyme immobilization, such as biocompatibility, non-toxicity, low allergenicity, and biodegradability. Moreover, antioxidant, antimicrobial, and antitumor activities have been reported for this molecule, and these properties are affected by its degree of deacetylation and its molecular weight [35]. Therefore, chitosan is an important shell material to entrap enzymes that can be used for several applications in different fields. As enzyme immobilization matrices, chitosan-based materials are used primarily in the form of gels of different geometrical configurations, such as beads/spheres, membranes, fibers, and sponges [36].

Different studies have proposed strategies to promote the chitosan transition into sol-gel in recent years. Chitosan gels can essentially be formed in two ways: by "physical" or "chemical" reticulation processes. In the latter case, permanent networks are formed when covalent bonds among chains are exploited. Typically, glutaraldehyde, diglycidyl ether, diacrylate, diisocyanate, or small molecules are used in the preparation of chemical gels of chitosan. However, it is a concern that the toxicity of the majority of such molecules could represent a risk to the environment and living beings [37]. 
Due to its lower toxicity, physical chitosan gels are, perhaps, more suitable for use as systems for enzyme entrapment. Moreover, the possibility of tuning extent and the rate of gel swelling, mechanical behavior, and degradation are also appealing characteristics of physical chitosan gels. By varying physical and chemical parameters-temperature, ionic strength, and $\mathrm{pH}$ - or adding proper counterions, the physical gels are likely to transition to sol-gel. Entangled networks are formed when hydrophobic interactions and electrostatic and hydrogen bonds react. Ionic strength and $\mathrm{pH}$, in relation to ionic interactions, are crucial in gel formation [38].

Chitosan concentration exerts a strong influence on gel formation for enzyme retention by the capsules/beads. According to Nunes et al. [3], when the chitosan concentration was increased from 2 to $5 \%(w / v)$, the enzyme encapsulating efficiency increased significantly.

Some biopolymers, such as chitosan, alginate, and carrageenan, can be used in the preparation of hybrid supports in order to entrap enzymes. Chitosan can play a key role in the preparation of hybrid polymers, leading to polyelectrolyte complex products formation when in the presence of natural polyanions. Chitosan-alginate hybrid gel is formed when the amine groups of chitosan and the carboxyl groups of other polymers interact electrostatically in a strong manner. As a consequence of being stronger than pure chitosan, the complex shows a higher activity under extreme mechanical stirring and temperature [39].

\subsection{Alginate}

Alginate is the most frequently used polymer for enzyme encapsulation [40]. It is a naturally derived polymer primarily found as a structural component of marine brown seaweed (Laminaria hyperborea and Macrocystis pyrifera) and as capsular polysaccharides in some soil bacteria such as Pseudomonas and Azotobacter [41]. In general, alginate is a linear polysaccharide copolymer composed of two C5 epimer repeating units, (1-4)-linked $\beta$-dmannuronic acid ( $\mathrm{M}$ units) and $\alpha$-l-guluronic acid ( $\mathrm{G}$ units) monomers. Within the alginate polymer, the $M$ and $G$ units are sequentially assembled in either repeating (-M-M- or -G-G-) or alternating (-M-G-) blocks [42]. The amount and distribution of each unit depend on the alginate source, and these blocks determine the polymer properties and behavior. The ratio between $M$ and $G$ units significantly affects transmittance, viscoelasticity, and swelling [43]. The carboxylic groups in alginate can form salts, such as sodium alginate, by their attachment to the monovalent ions.

Alginate can be prepared in either neutral or charged form, and so it is compatible with a broad variety of substances. Depending on media $\mathrm{pH}$, alginate can form two types of gel, an acid or an ionotropic gel, which provide many physicochemical properties [44,45].

An important feature of alginate and its derivatives is its gelation in the presence of divalent cations such as calcium $\left(\mathrm{Ca}^{2+}\right)$ through the ionic interaction between these cations and the carboxyl groups located on the polymer backbone. The most widely used cation for alginate hydrogels preparation is calcium, since it is an essential element for humans and is easily accessed [46]. The alginate gelation by calcium ions is due mainly to the ionic crosslinking between guluronic acid units located on adjacent alginate chains. This solution-gel transition process is called crosslinking. The crosslinked hydrogel has an "egg-box" structure.

Alginate hydrogels are nontoxic and immunologically inert materials with a high level of biocompatibility and biodegradability. They can easily undergo gelation with divalent cations under mild conditions suitable for the incorporation of biomacromolecules. Alginate-based microencapsulation is currently a favored approach for enzyme encapsulation $[47,48]$. A relatively simple and safe technique to entrap enzymes is the use of calcium alginate beads [49-51]. An aqueous solution of sodium alginate is mixed with the enzyme when added drop-wise in a solution of $\mathrm{Ca}^{2+}$, the droplets can precipitate, and the biocatalyst is entrapped [52]. In a $2 \%$ solution, calcium alginate beads are formed, resulting in 80 to $100 \AA$ of average pore diameter [53-55]. The carboxyl groups of alginate provide multiple sites for ionic crosslinking with the positively charged amino acids present on 
enzymes structure. The enzyme and the support interact, improving the conformational stability of the immobilized enzyme and then increasing the shelf life [56]. According to Pereira et al. [57], sodium alginate titer can influence the enzyme entrapment immensely. At low concentrations $(<1 \%)$, the viscosity of this polymer is low, which can cause internal mixing of the components during complexation, delaying the formation of a semipermeable surface that reduces enzyme retention. At higher concentrations $(>1 \%)$ of this polymer, the enzyme retention increases, but above $4 \%(w / v)$, a small reduction in immobilization yield is observed, which is associated with viscosity increase. It is more difficult to extrude through the syringe needle when the viscosity is high, and, consequently, the formation of microcapsules is not uniform. Zusfahair et al. [58] studied the immobilization of amylase from Aspergillus oryzae and observed a reduction in immobilization yield while increasing alginate concentration. Conformational changes in the entrapped enzyme and limitation of substrate mass transfer to the microcapsules can be caused by increasing sodium alginate concentration.

Low mechanical strength, high leakage of the enzyme from beads, and large pore size are some disadvantages $[53,54,59]$ which may be reduced by blending alginate with chitosan [57,60-63], kaolinite clay [64,65], gelatin [66,67], poly-L-lysine [68], and other polymers. The crosslinking of anionic alginate with cationic compounds results in a more controlled microcapsule pore size and stability improvement [67].

\subsection{Carrageenan}

Carrageenan is the name for a family of gel polysaccharides formed by a sulfated polygalactan that contains ester sulfate at about $15-40 \%$. It is formed by alternating units of 3,6-anhydro-galactose and D-galactose, joined by $\beta-1,4$ and $\alpha-1,3$ glycosidic linkage [69]. Carrageenan is extracted from red seaweed and can present various beneficial effects due to the variability of its structure and properties. The number of sulfate ester groups in a carrageenan molecule and its position, as well as the content of 3,6-anhydro-galactose, can influence the properties of the biopolymer [70].

Carrageenan has been produced in six types $\left(\kappa-, l_{-}, \lambda-, \mu-, v_{-}\right.$, and $\theta$-carrageenan) based on their structures [71]. Due to its high gelling ability, $\mathrm{k}$-carrageenan is the most produced polymer. The enormous number of $-\mathrm{OH}$ supports the formation of the helix structure, forming many hydrogen bonds [72]. Gels produced with k-carrageenan are hard, strong, and brittle. According to Geonzon et al. [73], the generally accepted model of the gelling process of carrageenan solutions involves the coil-to-helix transition, followed, in the presence of certain cations, by the aggregation of double helices to form a spanning network.

Zheng et al. [74] investigated the potential of carrageenan hydrogel beads for encapsulating $\beta$-galactosidase. The hydrogel beads were formed by injecting a $\beta$-galactosidase $/ \mathrm{k}$ -carrageenan solution into a potassium chloride hardening solution. The cationic potassium ions $\left(\mathrm{K}^{+}\right)$promote gelation of the anionic $\mathrm{k}$-carrageenan molecules by acting as salt bridges. In comparison with the free enzyme under certain thermal and $\mathrm{pH}$ conditions, the activity of encapsulated $\beta$-galactosidase was raised. In a recent study, pectin, carrageenan, and their hybrid hydrogels were investigated using the ionotropic gelation method for the encapsulation of $\beta$-galactosidase. As a result, the carrageenan hydrogel presented the best stability after three months, and its activity and release were considered better than that of the pectin hydrogel [75].

Much research on enzyme entrapment uses a k-carrageenan as a wall material, such as for the entrapment of invertase [76], alpha-amylase [49], papain [50], urease [77], pancreatin [78], lactase [79], lipase [80,81], and glucoamylase [82].

\subsection{Pectin}

Pectin is a complex mixture of polysaccharides extracted from plant cell walls. Commercially available pectins are almost totally derived from citrus peels or apple pomace, which are by-products from the juice industry. Like the majority of other plant polysac- 
charides, it is polymolecular and polydisperse. In addition, its composition can vary depending on the source and the conditions faced during isolation [83].

Pectin consists mainly of D-galacturonic acid units, joined in chains through $\alpha-(1-4)$ glycosidic linkage. Pectin also has branch regions consisting of mono-sugars, such as D-xylose, D-glucose, L-rhamnose, L-arabinose, or D-galactose [84]. Some of the carboxyl groups of the uronic acids present in pectin chains are naturally present as methyl esters, and others are commercially treated with ammonia to produce carboxamide groups. The percentage of D-galacturonic acid esterified with methanol is denominated by the degree of methoxylation. According to the degree of the methoxylation, pectin can be classified into two groups: high methoxy pectin (HMD), with a degree of methylation $>50 \%$, and low methoxy pectin (LMD), with a $\mathrm{DM}<50 \%$ [85].

Pectin has been employed as a gelling agent, a thickening agent, and a colloidal stabilizer for the last two centuries and is extensively applied in the food and pharmaceutical industries [86]. Due to its excellent gelling properties, pectin has been employed as a support material for enzyme entrapment. In an acidic environment (typically, $\mathrm{pH} \leq 3$ ) or with a high concentration co-solute (e.g., sucrose, $\geq 65 \mathrm{wt} \%$ ), the gelation of high methoxy pectin occurs through crosslinking between the hydrophobic forces and methyl bonds [87].

Calcium dependent gelation is one of the most important functional properties of pectin that allows for enzyme entrapment. In this case, low methoxy pectin forms a gel in the presence of calcium ions. The gelation mechanisms of alginate and pectin, known as the egg-box model, were believed to be similar because their Ca-binding sites show a mirrorsymmetric conformation. Nonetheless, the formation and the structure of egg-box dimmers between alginate and pectin differs, as studies have found [85]. Molecular modeling showed that the most well-disposed association of pectin chains should demonstrate a better correlation if described by a "shifted" egg-box [88].

In general, in order to keep a biocatalyst entrapped inside the pectin hydrogel network, pectins are used in the form of microbeads. The lipase encapsulation in pectin gels crosslinked with calcium ions increased enzyme activity by three to four times in water-miscible organic co-solvents compared with aqueous systems [89]. In another study, two enzymes were immobilized in pectin, presenting greater thermal and $\mathrm{pH}$ stability in comparison to the free enzyme system with the complete retention of original activities [90]. The bioactivity of the enzyme encapsulated depends on bead formulation and process parameters. $\beta$-lactamases encapsulated in pectin beads mainly depend on formulation parameters such as pectin type, $\mathrm{CaCl}_{2}$ concentration, and washing and drying processes [91].

Different hybrid supports based on pectin were described for enzyme encapsulation, such as a pectin/alginate [92-94], pectin/poly-vinyl alcohol [95], pectin/chitosan [96], carrageenan/pectin [75], and pectin/pine fiber [97]. The pectin combination with other polymers improves some key properties, such as mechanical and thermal resistances.

\subsection{Agar-Agar and Agarose}

Agar-agar is a natural polysaccharide obtained from the cell wall of Rhodophyta (red algae), and its main components are neutral agarose and charged agaropectin [98]. Agarose, the predominant component, is formed by agarobiose that consists of repeating units of $\beta$-D-galactose and 3,6-anhydro-L-galactose linked by the $\alpha-(1 \rightarrow 3)$ and $\beta$-(1 $\rightarrow 4)$ glycosidic bond [99]. Agaropectin, a sulfated polysaccharide (3-10\% sulfate), has the same repeating unit, but about $8 \%$ of the 2 - or 6-positions of the 3,6-anhydro- $\alpha$-L-galactose residues can be substituted by $-\mathrm{OSO}_{3},-\mathrm{OCH}_{3}$, glucuronate, or pyruvate residues. The gelling potential of the material is greatly affected by these substituents [100].

Agar-agar and agarose gels have been used as a wall material for enzyme encapsulation because of some favorable functional properties [101-105]. Agarose, when in aqueous media, is a typical strongly hydrophilic, inert, and lyophilic colloid. Moreover, the ability of agar and agarose to form firm and stable gels is their most appealing characteristic [106]. 
Due to its physico-chemical properties and molecular structure, agarose transits into sol-gel after cooling and forms a three-dimensional network [107]. To form double helices, the single chains first associate via hydrogen bonds during gelation under cooling conditions. When the temperature drops even further, the double helices aggregate [108]. A two-step gelation mechanism was proposed: firstly, the connection between the randomly distributed coils by hydrogen bonds is formed, and a double-helical association is made; then, the double helices aggregate, forming a tight, three-dimensional network [109]. Moreover, the coil-to-helix transition, which occurs while cooling, may be described by a mean-field Zimm-Bragg approach [110].

The pore size of the gel matrix is regulated by the agarose concentration, which affects the immobilization yield of the enzyme and its catalytic performance. A fragile gel matrix with large pores is produced with a lower concentration, leading to the leaking of enzyme molecules. In contrast, small pore size within the gel matrix is caused by high concentration, creating hurdles in the penetration of high molecular weight substrates [111,112]. The maximum immobilization yield (\%) of the enzyme was achieved when $2.0 \%$ agarose was used, according to Karim et al. [113]. Through an entrapment technique, these authors encapsulated carboxymethyl cellulase from Bacillus licheniformis KIBGE-IB2 within the agarose gel matrix. After it was immobilized, the enzyme's activation energy (Ea) increased from 16.38 to $44.08 \mathrm{~kJ} / \mathrm{mol}$. The immobilized enzyme exhibited higher catalytic activity in a broad range of $\mathrm{pH}$ and temperature as compared to native enzymes. Furthermore, the operational and storage stabilities were also found to be significantly higher when the enzyme was immobilized.

The agar-agarose blend was used as a wall material for $\alpha$-amylase entrapment [114]. Maximum immobilization yield (19.9\%) was obtained with beads prepared with $1.0 \%(w / v)$ agarose and $4.0 \%(w / v)$ agar. The immobilized enzyme had a hydrolytic activity nearly $25 \%$ higher when compared to that of the free enzyme.

Serine protease produced by Aspergillus niger KIBGE-IB36 was encapsulated in agaragar hydrogel, and maximum enzymatic activity was attained when $3.0 \%$ agar-agar was used. The immobilized protease exhibited a significant increase in the thermal stability and retained approximately $68.0 \%$ of its residual activity at $60{ }^{\circ} \mathrm{C}$. As the entrapped protease showed enzymatic activity, storage stability increased up to 30 days compared to the soluble enzyme. The enzyme was recycled up to eight cycles, presenting an exceptional attribute for economic utility and the continuous recycling of protease [115].

\subsection{Gelatin}

Gelatin is a protein of animal origin that is derived from the chemical degradation of collagen. Cattle bones, hides, pig skins, and fish are the main commercial sources of gelatin and can be obtained inexpensively. It has a high molecular weight from 65,000 to $300,000 \mathrm{~g} / \mathrm{mol}$ [116]. Chemically, gelatin comprises 18 varieties of complex amino acids, with glycine, proline, and hydroxyproline as the major compounds, and other distinguished amino acid families, such as glutamic acid, alanine arginine, and aspartic acid [117]. Due to its excellent biodegradability, low cytotoxicity, and indefinite shelf life, gelatin has attracted attention for enzyme immobilization [118].

Gelatin can form a heat-reversible gel in dilute aqueous solutions [119] and a hydrophilic, macroporous hydrogel containing hydroxyl groups as well as charged groups $\left(-\mathrm{NH}_{2},-\mathrm{COOH}\right)$. All these available groups on the molecular chains can be activated and then covalently conjugated with polymeric gelatin chains by crosslinking agents such as microbial transglutaminase [120]. Transglutaminase presents a singular ability of protein crosslinking, catalyzing acyl-transfer reactions between $\gamma$-carboxyamide groups of glutamine residues and $\varepsilon$-amino groups of lysine residues [121]. According to Labus et al. $[67,122]$, gelatin-based hydrogels crosslinked with transglutaminase are suitable to be used as matrices for invertase and $\beta$-galactosidase entrapment.

Physical, enzymatic, and chemical methods can be used to develop an efficient procedure to prepare gelatin hydrogels of appropriate strength and elastic properties for 
applications as enzyme carriers. Generally, gelatin microspheres are prepared primarily using (1) spray-drying, (2) coacervation, (3) emulsion, or (4) membrane emulsification methods $[118,123,124]$. The immobilization of enzymes onto gelatin takes place via crosslinking between the enzyme molecule with crosslinking agents and the free amino groups of the carrier, leading to the formation of a covalent bond, according to Ewadh and Al-Khafaji [125]. Gan et al. [126] elaborated a glucoamylase-immobilized system based on crosslinked gelatin nanoparticles using the coacervation method. This system exhibited characteristics of temperature-triggered phase transition, which could be used for enzyme immobilization and release. The efficiency of the loadings of immobilized glucoamylase by entrapment was $59.9 \%$. The immobilized enzyme was released when the system temperature was above $40^{\circ} \mathrm{C}$.

Gelatin behaves like an amphoteric electrolyte in solution (carrying a net positive charge below its isoelectric $\mathrm{pH}$ ). It is also known to interact via non-covalent interactions with other hydrocolloids, including alginate, gellan, carrageenan, and konjac glucomannan [127]. Efficient enzyme immobilization includes laccase [128], $\beta$-glucosidase [129], $\alpha$-amylase [130], and lipase [131] by using gelatin along with calcium alginate, polyester films, and titanium species [132].

\subsection{Polyethylene Glycol (PEG)}

Polyethylene glycol (PEG) is a hydrophilic polymer composed of repeated ethylene glycol units $\left[-\left(\mathrm{CH}_{2} \mathrm{CH}_{2} \mathrm{O}\right)_{n}\right]$. It can be synthesized by anionic polymerization of ethylene oxide and a hydroxyl group (from water, ethylene glycol, or any diols). Ring-opening polymerization of epoxyethane is another way to produce PEG. Commercially available PEGs are found with different degrees of polymerization and activated functional groups [133].

From the synthetic polymers, polyethylene glycol stands out as an encapsulating material for enzyme systems because of its non-immunogenic, biocompatible, and flexible nature [134]. The mechanical stability of PEG can be enhanced by mixing it with other polymers, such as alginate, chitosan [135], and poly (lactic-co-glycolic acid) (PLGA) [136].

Wang et al. [135] showed that PEG added into sodium alginate-immobilized cellulase increased the matrix porosity. The addition of chitosan reduced the disintegration of the carrier to improve its stability. Cellulase immobilized in a sodium alginate-PEG-chitosan matrix was used to hydrolyze microcrystalline cellulose with an overall yield $23 \%$ higher than that of the free cellulase after reusing it for five cycles.

Labile hydrophilic enzymes for neurological disease applications can also be delivered by polymeric particles made of PEG. PLGA copolymerized with PEG has been used to protect catalase from degradative proteases [136]. Sonicated nanoparticles of PEG-PLGA containing catalase increased the enzyme activity and showed great protection of the enzyme in degradative conditions. The authors, however, were alert for possible toxicity caused by the solvent used during sonication. Replacing dichloromethane with chloroform resulted in biocompatible polymeric nanoparticle formulations [136].

PEG was also used to encapsulate laccase for bisphenol A removal from aqueous solution [137]. The particles were prepared by encapsulating laccases into PEG hydrogel via the UV-assisted emulsion polymerization method followed by cross linking with glutaraldehyde. High enzyme entrapment efficiency and activity recovery were obtained, resulting in successful bisphenol degradation for seven cycles.

\section{Enzyme Encapsulation Methods}

The selection of the encapsulating method is of great importance for the success of micro or nanostructured systems for enzyme loading. In recent decades, several methods have been studied for this purpose, especially ionic gelation, spray drying [16,57], freeze-drying [138,139], nanoprecipitation [18,140], and electrospinning [19,141]. A good encapsulation method should enable high loading capacity, high encapsulation efficiency, and high stability. The release and bioavailability characteristics of the capsule must also be considered for enzyme delivery [142,143]. 
Table 1 shows some recent studies of enzymatic encapsulation using polymers, and the main results are reported.

Table 1. Recent research about the encapsulation of enzymes using polymeric matrices.

\begin{tabular}{|c|c|c|c|c|}
\hline $\begin{array}{l}\text { Encapsulation } \\
\text { Method }\end{array}$ & Enzyme & $\begin{array}{l}\text { Encapsulating } \\
\text { Polymers }\end{array}$ & Main Results & Refs. \\
\hline $\begin{array}{l}\text { Liposome } \\
\text { entrapment }\end{array}$ & Superoxide dismutase & Polyacrylamide & $\begin{array}{l}\text { Good encapsulation efficiency (37\%) and } \\
\text { maintenance of enzyme activity. }\end{array}$ & [144] \\
\hline $\begin{array}{l}\text { Emulsion solvent } \\
\text { evaporation }\end{array}$ & $\begin{array}{l}\alpha \text {-chymotrypsin and } \\
\text { lysozyme }\end{array}$ & $\begin{array}{l}\text { Poly (glycerol adipate- } \\
\text { co-o-pentadecalactone) } \\
\text { Poly (1,3-propanediol } \\
\text { adipate-co-o- } \\
\text { pentadecalactone) }\end{array}$ & $\begin{array}{l}\text { Little difference in encapsulation was } \\
\text { observed between the different polymers; } \\
\text { Changes in polymer chemistry showed } \\
\text { greater effects. }\end{array}$ & [145] \\
\hline $\begin{array}{c}\text { Crosslinked } \\
\text { enzyme aggregates }\end{array}$ & $\begin{array}{l}\text { Thioesterase, } \\
\text { galactosylceramidase, } \\
\alpha \text {-glucosidase, and } \beta \text { - } \\
\text { glucosidase }\end{array}$ & $\begin{array}{c}\text { Poly } \\
\text { (lactide-co-glycolide) }\end{array}$ & $\begin{array}{c}\text { Excellent activity retention (usually } \\
\text { around } 60 \% \text { ); enzymatic activity is fully } \\
\text { recovered in primary fibroblasts upon } \\
\text { treatment. }\end{array}$ & [146] \\
\hline $\begin{array}{l}\text { Solid-in-oil-in- } \\
\quad \text { water }\end{array}$ & $\alpha$-chymotrypsin & $\begin{array}{l}\text { Poly (lactic-co-glycolic) } \\
\text { acid }\end{array}$ & Maximum encapsulation efficiency of $61 \%$. & [147] \\
\hline $\begin{array}{l}\text { Precipitation- } \\
\text { dialysis }\end{array}$ & $\alpha$-chymotrypsin & Poly ( $\gamma$-glutamic acid) & $\begin{array}{l}\text { Considerable amounts of } \alpha \text {-chymotrypsin } \\
\text { were encapsulated ( } 20-25 \%) \text {; the } \\
\text { encapsulation contributed to the } \\
\text { preservation of enzyme activity over time. }\end{array}$ & [148] \\
\hline Adsorption & Alcohol dehydrogenase & $\begin{array}{l}\text { Polyallylamine } \\
\text { Polystyrene sulfonate }\end{array}$ & $\begin{array}{l}\text { The affinity of alcohol dehydrogenase to } \\
\text { the substrate was } 1.7 \text { times lower than } \\
\text { that of the native enzyme. }\end{array}$ & [149] \\
\hline Polymerization & Glucose oxidase & - & $\begin{array}{l}\text { Thermal stability and tolerance to organic } \\
\text { solvents were significantly improved. }\end{array}$ & [150] \\
\hline Homogenization & Naringinase & $\begin{array}{l}\text { Sodium alginate or } \\
\text { chitosan }\end{array}$ & $\begin{array}{l}\text { The process improved the kinetics and } \\
\text { operational stability, so it could be useful } \\
\text { as a debittering agent for citrus juice } \\
\text { industries. }\end{array}$ & [151] \\
\hline \multirow{3}{*}{ Electrospinning } & Lysozyme & $\begin{array}{l}\text { Poly(vinylpyrrolidone) } \\
\text { and Eudragit RS100 }\end{array}$ & $\begin{array}{c}\text { High encapsulation efficiency and } \\
\text { preservation of enzyme activity were } \\
\text { achieved ( } 93.4 \pm 7.0 \% \text { and } 96.1 \pm 3.3 \% \text {, } \\
\text { respectively). }\end{array}$ & [19] \\
\hline & Fructosyltransferase & $\begin{array}{l}\text { Group of } \\
\text { biodegradable } \\
\text { polymers }\end{array}$ & $\begin{array}{l}\text { Good results have been obtained; } \\
\text { however, further research is needed to } \\
\text { reduce the leaching of the encapsulated } \\
\text { enzyme from electrophilized fibers. }\end{array}$ & [141] \\
\hline & $\beta$-galactosidase & Polyvinylpyrrolidone & $\begin{array}{l}97 \% \text { of the original activity was } \\
\text { maintained; there were no changes in } \mathrm{pH} \\
\text { and temperature profiles; high storage } \\
\text { stability ( } \beta \text {-galactosidase activity } \\
\text { decreased by only } 4 \% \text { after one year). }\end{array}$ & [152] \\
\hline Electrospray & Streptokinase & $\begin{array}{l}\text { Poly (lactic-co-glycolic } \\
\text { acid) }\end{array}$ & $\begin{array}{l}\text { The method proved to be an interesting } \\
\text { approach to encapsulate enzymes; other } \\
\text { studies are necessary to ensure the } \\
\text { maintenance of enzyme activity after } \\
\text { electrospray. }\end{array}$ & [153] \\
\hline
\end{tabular}


Table 1. Cont.

\begin{tabular}{|c|c|c|c|c|}
\hline Encapsulation Method & Enzyme & $\begin{array}{l}\text { Encapsulating } \\
\text { Polymers }\end{array}$ & Main Results & Refs. \\
\hline \multirow{2}{*}{ Freeze-drying } & Bromelain & Chitosan & $\begin{array}{l}\text { The freeze-dried method can } \\
\text { effectively improve the stability of } \\
\text { bromelain and nanoparticles. }\end{array}$ & [138] \\
\hline & Firefly luciferase & $\begin{array}{l}\text { Chitosan and xanthan } \\
\text { gum }\end{array}$ & $\begin{array}{l}\text { Enzymatic activities of the } \\
\text { encapsulated and the released enzyme } \\
\text { were confirmed for over } 30 \text { days. }\end{array}$ & [139] \\
\hline \multirow{3}{*}{ Nanoprecipitation } & $\begin{array}{l}\text { Lysozyme and } \\
\text { horseradish peroxidase }\end{array}$ & $\begin{array}{l}\text { Poly (lactic acid) } \\
\text { Poly (ethylene glycol) }\end{array}$ & $\begin{array}{c}\text { Lysozyme and horseradish peroxidase } \\
\text { were shown to retain } 99 \% \text { activity } \\
\text { after processing. }\end{array}$ & [18] \\
\hline & Asparaginase & Polyglycerol & $\begin{array}{l}\text { Enzymes were encapsulated with an } \\
\text { efficacy of } 100 \% \text { and, after release, full } \\
\text { enzyme activity and structural } \\
\text { integrity were retained. }\end{array}$ & [140] \\
\hline & $\begin{array}{l}\text { Lysozyme and } \\
\alpha \text {-chymotrypsin }\end{array}$ & $\begin{array}{l}\text { Poly (lactic-co-glycolic) } \\
\text { acid }\end{array}$ & $\begin{array}{l}\text { High encapsulation efficiencies }(>70 \%) \\
\text { and residual activity }(>90 \%) .\end{array}$ & [154] \\
\hline Coacervation complex & Lysozyme & $\begin{array}{l}\text { Poly (acrylic acid)-block- } \\
\text { poly(acrylamide) } \\
\text { Poly( } N, N- \\
\text { dimethylaminoethyl } \\
\text { methacrylate) }\end{array}$ & $\begin{array}{c}\text { The stability of the micelles containing } \\
\text { a larger fraction of lysozyme was } \\
\text { lower. }\end{array}$ & [155] \\
\hline Extrusion & $\alpha$-amylase & Gelatin and shellac & $\begin{array}{l}\text { The enzyme showed good stability } \\
\text { after encapsulation and can be } \\
\text { recycled } 10 \text { times. }\end{array}$ & [132] \\
\hline Thermal gelation & $\begin{array}{l}\text { L-phenylalanine } \\
\text { ammonia-lyase }\end{array}$ & Plant hydrocolloids & $\begin{array}{l}\text { Good results were obtained; however, } \\
\text { new studies are necessary. }\end{array}$ & [156] \\
\hline \multirow{2}{*}{ Spray drying } & $\beta$-galactosidase & Chitosan & $\begin{array}{l}\text { Encapsulation increased the } \\
\text { diffusional effect of the released } \\
\text { enzyme and reduced the initial } \\
\text { activity of the enzyme. }\end{array}$ & [157] \\
\hline & DNase I & $\begin{array}{l}\text { Poly (lactic-co-glycolic) } \\
\text { acid }\end{array}$ & $\begin{array}{c}\text { High encapsulation efficiency }(>80 \%) \\
\text { microparticles loaded with DNase I } \\
\text { showed high inhalation rates and } \\
\text { increased mucolytic activity. }\end{array}$ & [16] \\
\hline \multirow[b]{2}{*}{ Double emulsion } & Laccase & Eudragitfi L 100-55 & $\begin{array}{l}\text { Increased stability of the enzyme at } \\
\text { acidic pHs (2.0-5.0). }\end{array}$ & [158] \\
\hline & $\alpha$-chymotrypsin & $\begin{array}{l}\text { Poly (ethylene } \\
\text { glycol)-co-poly } \\
\text { (glycerol } \\
\text { adipate-co- } \omega- \\
\text { pentadecalactone) }\end{array}$ & $\begin{array}{l}\text { Good throughput and encapsulation } \\
\text { efficiency; encapsulation kept the } \\
\text { bioactivity of } \alpha \text {-chymotrypsin and } \\
\text { protected it from adverse preparation } \\
\text { conditions. }\end{array}$ & [159] \\
\hline \multirow[t]{2}{*}{ Layer-by-layer } & Catalase & $\begin{array}{l}\text { Poly (allylamine } \\
\text { hydrochloride) dextran } \\
\text { sulfate }\end{array}$ & $\begin{array}{l}\text { Catalase remained active inside the } \\
\text { polymer capsules; polymer capsules } \\
\text { showed potential to prevent oxidative } \\
\text { stress. }\end{array}$ & [160] \\
\hline & $\mathrm{L}$-asparaginase & $\begin{array}{l}\text { Poly dextran/poly-L- } \\
\text { arginine }\end{array}$ & $\begin{array}{l}\text { Encapsulation improved proteolytic } \\
\text { resistance and thermal inactivation of } \\
\text { L-asparaginase. }\end{array}$ & [161] \\
\hline
\end{tabular}


Table 1. Cont.

\begin{tabular}{cccc}
\hline Encapsulation Method & Enzyme & $\begin{array}{c}\text { Encapsulating } \\
\text { Polymers }\end{array}$ & Main Results \\
\hline & $\begin{array}{c}\text { Human phenylalanine } \\
\text { hydroxylase }\end{array}$ & Chitosan & $\begin{array}{c}\text { Effective in maintaining protein } \\
\text { stability and enzymatic function. }\end{array}$ \\
\cline { 2 - 5 } Ionic gelation & Bromelain & Chitosan & $\begin{array}{c}\text { High encapsulation efficiency }(85.1 \%) ; \\
\text { improved the stability of bromelain. }\end{array} \quad[138]$ \\
\cline { 2 - 5 } & Pectinase & Sodium alginate & $\begin{array}{c}\text { Pectinase can be used to hydrolyze } \\
\text { pectic substances in orange juice; } \\
\text { maintenance of enzyme stability } \\
\text { activity during recycles. }\end{array}$ \\
\cline { 2 - 5 } & Lipase & $\begin{array}{c}\text { Sodium alginate and } \\
\text { Chitosan }\end{array}$ & $\begin{array}{c}\text { High encapsulation yield (99.8\%); } \\
\text { improvement of enzyme activity. }\end{array}$ \\
\hline
\end{tabular}

As can be seen in Table 1, numerous techniques can be used in enzyme encapsulation, especially ionic gelation, spray drying, freeze-drying, nanoprecipitation, and electrospinning. $\alpha$-chymotrypsin, lysozyme, and $\beta$-galactosidase are the most used enzymes in encapsulation studies with polymeric matrices (Table 1). The most prominent polymers are chitosan and sodium alginate, which may be related to the abundance of these polymers in nature. Furthermore, most authors reported high encapsulation efficiency $[16,19,57,138,140,152,154]$, improvement or maintenance of enzyme activity $[16,19,57,138,144,148,151,152,162]$, improved $\mathrm{pH}$, temperature or storage stability $[150-152,158,161]$, and high reuse capacity $[132,163]$. The most widely used methods for entrapping enzymes are described in the next sections.

\subsection{Ionic Gelation}

Ionic gelation is often used to prepare micro/nanoformulations for the controlled release of enzymes. In this method, solutions of biopolymers (e.g., alginates, carboxymethylcellulose, chitosan) are dripped/sprayed under constant agitation to solutions containing divalent or trivalent cations (for example, $\mathrm{Ca}^{2+}, \mathrm{Sr}^{2+}, \mathrm{Ba}^{2+}, \mathrm{Al}^{3+}$ ), which induce gelation [14]. Encapsulation occurs by dissolving the enzyme in the polymeric solution before the microparticle formation process. Ionic gelation is a simple and easy method, does not require specialized equipment, organic solvent, or high temperatures, and can be considered low cost $[164,165]$. Figure 1a illustrates an example of enzyme encapsulation by the ionic gelation method.

Studies carried out by Bahreini et al. described the immobilization of L-asparaginase on chitosan nanoparticles by the ionotropic gelling method using tripolyphosphate as anion [166]. The authors reported that the best chitosan/tripolyphosphate ratio was 4.2, with an encapsulation efficiency of $76.2 \%$. In addition, the immobilized enzyme showed an increase in half-life of about 23 days in the low ionic strength solution compared to the free enzyme. Vimal and Kumar [167] also immobilized L-asparaginase in chitosan nanoparticles by the ionic gelling method and obtained an encapsulation efficiency and loading capacity of $72 \%$ and $53 \%$, respectively. Encapsulation of L-asparaginase inside the nanocarrier improved its $\mathrm{pH}$ and thermal stability. 

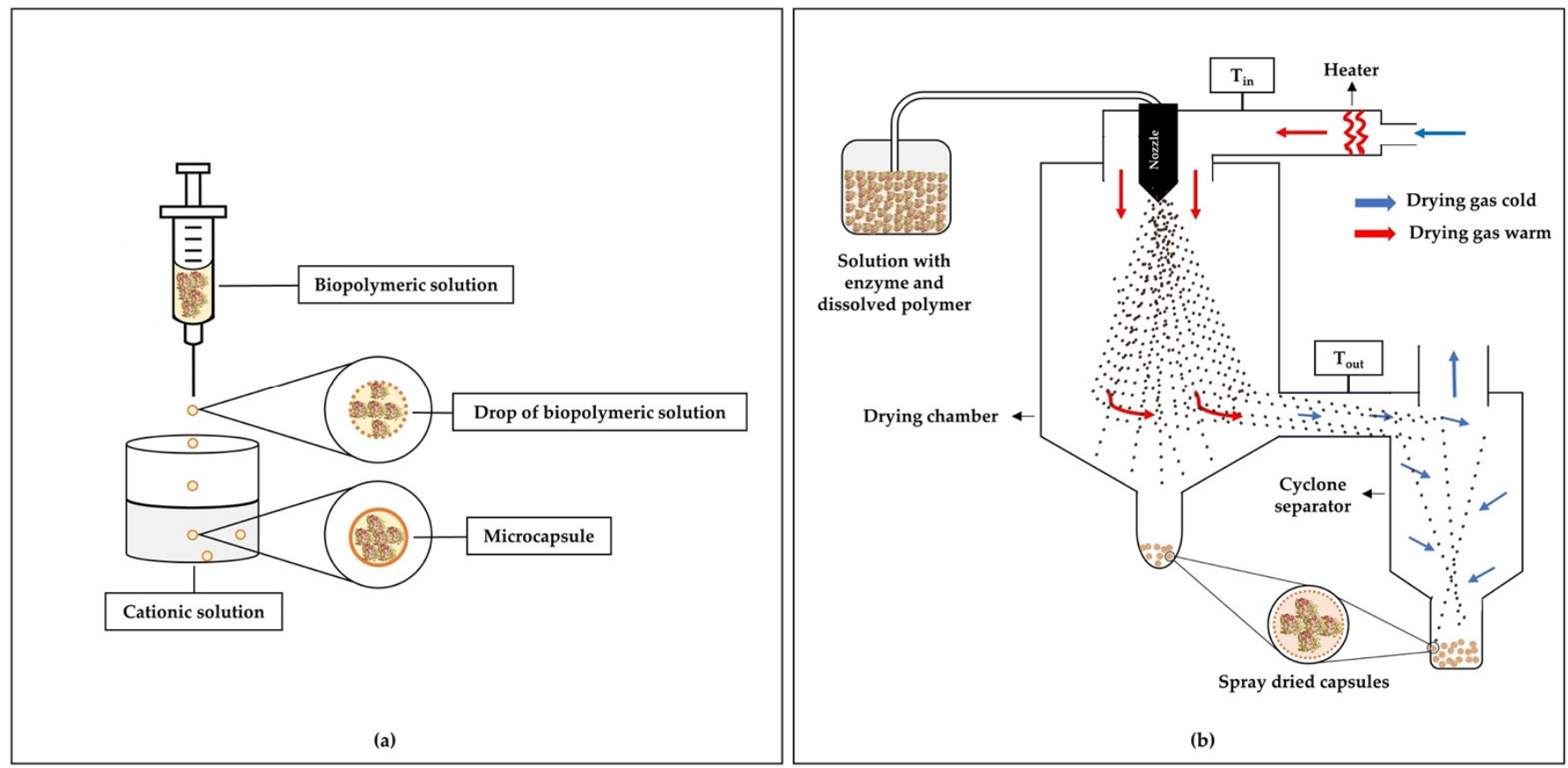

Figure 1. Schemes for encapsulation of enzymes using polymers: (a) ionic gelation method and (b) spray drying method.

Degradation studies of various textile dyes with horseradish peroxidase encapsulated in chitosan granules were evaluated by Bilal et al. [168]. In this study, the horseradish enzyme was effectively immobilized in chitosan granules ( $2.5 \%$ chitosan concentration) with an immobilization yield of $92.54 \%$ using a simple entrapment method. The optimum $\mathrm{pH}$ and temperature of the immobilized enzyme were 7.5 and $70{ }^{\circ} \mathrm{C}$, respectively. The dye discoloration potential by immobilized peroxidase was investigated in a fixed bed reactor system for four different textile dyes, namely Remazol Brilliant Blue R (RBBR), Reactive Black 5 (RB5), Congo Red (CR), and Crystal Violet (CV). Immobilized peroxidase resulted in effective dye removal of RB5 (97.82\%) followed by CR (94.35\%), CV (87.43\%), and RBBR $(82.17 \%)$. The immobilized peroxidase retained up to $64.9 \%$ of the residual activity after six consecutive cycles of dye decolorization.

Jaiswal et al. [169] immobilized a purified papaya laccase on chitosan granules using an entrapment approach. Papaya laccase was immobilized in chitosan granules with an immobilization yield and loading efficiency of $98 \%$ and $100 \%$, respectively. An increase in laccase properties, such as optimal temperature (at $10^{\circ} \mathrm{C}$ ), thermostability (by 3 times), and optimal pH (from 8.0 to 10.0), was observed after immobilization. Immobilization increased enzyme tolerance to a range of metal ions (including heavy metals) and organic solvents, namely, ethanol, isopropanol, methanol, benzene, and dimethylformamide (DMF).

\subsection{Spray Drying}

Spray drying is widely used to encapsulate active ingredients, such as flavonoids, lipids, carotenoids, and enzymes [16,157,170]. Spray drying is a continuous process that transforms various liquids (for example, solutions, emulsions, dispersions, slurries, pastes, or even melts) into solid particles with adjustable size, distribution, shape, porosity, density, and chemical composition [171]. In addition, it is a simple, fast, and relatively low-cost process.

In the encapsulation using the spray drying technique, the feed material is atomized inside the drying chamber, in which the water of the formed droplets is instantly evaporated due to contact with the hot air inside the chamber. The formed microparticles are then separated from the drying air using recovery cyclones [172]. The short contact time (a few seconds) of the heat with the formed particles makes spray drying encapsulation quite attractive for enzyme trapping. In addition, proteins and enzymes are more resistant to 
degradation by heat in conditions of low water content and are stabilized very quickly during rapid evaporation [173]. Figure $1 \mathrm{~b}$ shows a schematic of a traditional spray drying system used in the production of microparticles.

Estevinho et al. [157] encapsulated $\beta$-galactosidase using the spray drying method and chitosan as an encapsulating agent and observed an increase in the diffusional effect of the released enzyme and also a reduction in the initial enzyme activity. Ataide et al. [138] performed the encapsulation of bromelain in chitosan nanoparticles, aiming to reduce degradation by protease, increasing its stability and efficiency. The chitosan-bromelain nanoparticles were produced by ionic gelation/freeze-drying, and an encapsulation efficiency of $85 \%$ and an enzymatic activity of $4.9 \mathrm{U} / \mathrm{mL}$ were observed.

\subsection{Freeze-Drying}

Freeze-drying is an appropriate and widely used technique for microencapsulation of heat-sensitive compounds, as it removes water from microparticles by sublimation. It is a multi-stage operation that is divided into three stages: freezing, sublimation, and desorption. The freezing step converts most of the sample water to ice and then the ice is removed by sublimation at a very low temperature and pressure (step 2). Finally, the non-frozen water is desorbed to the desired moisture content [174].

The freeze-drying process alone is not capable of producing microparticles and, therefore, before this process, the enzyme needs to be encapsulated by another method that can form droplets of the desired size (e.g., emulsification), which are subsequently dehydrated by lyophilization, forming micro- or nanocapsules. Figure 2a shows an example of powdered nanocapsules containing enzymes produced using freeze-drying.
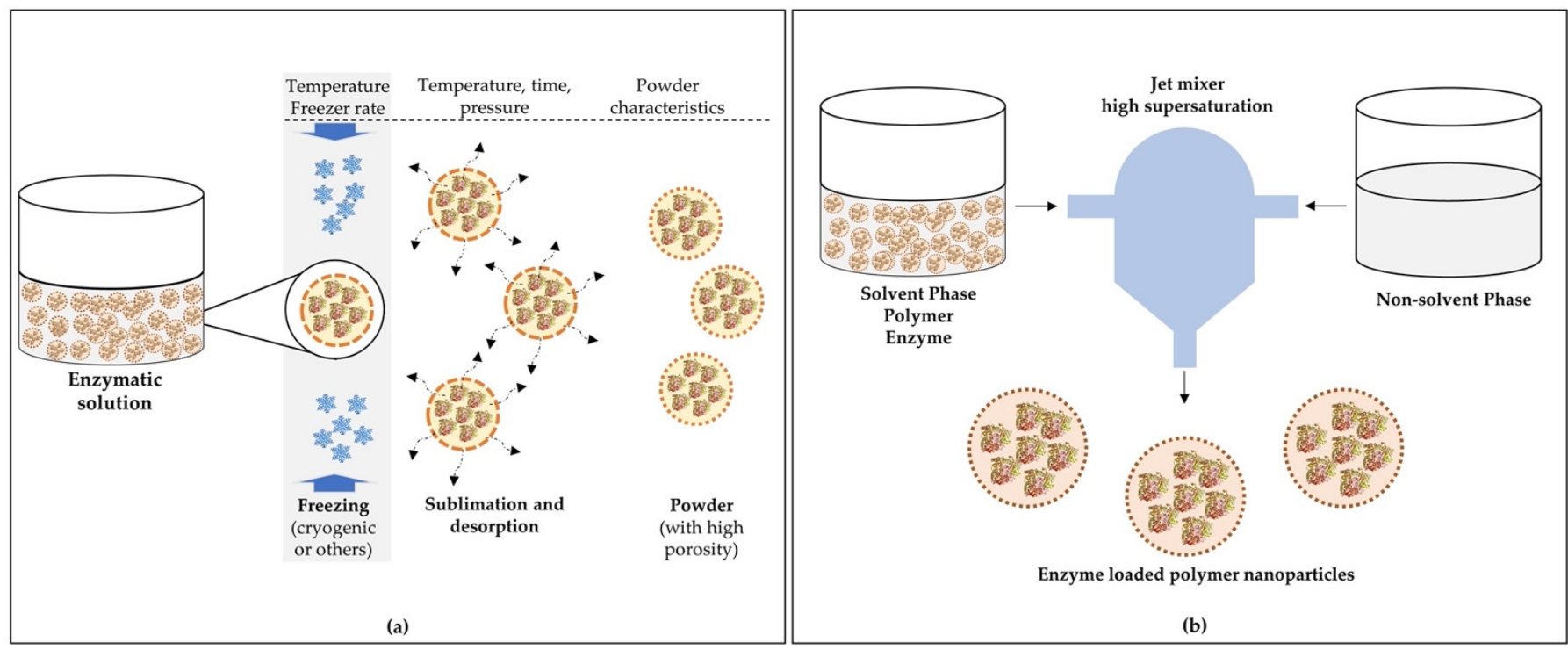

Figure 2. Schemes of capsule production loaded with enzymes by (a) a freeze-drying process and (b) the flash nanoprecipitation method. Adapted from Vishali et al. [175] and Martínez Rivas et al. [176].

Freeze-drying can also be applied as a complementary technique. Using the ionic crosslinking technique, the encapsulation of bromelain in chitosan nanoparticles resulted in high encapsulation yield and high enzymatic activity [138]. However, the particles were unstable in aqueous media, and lyophilization of the formulation with glycine and maltose as lyoprotectants was evaluated. The resulting microparticles showed short resuspension time, little changed average size, and increased encapsulation rate compared to the liquid form. Maltose has been identified as the best lyoprotectant for the maintenance of enzyme activity, especially when stored under refrigeration [138].

Firefly luciferase was encapsulated in a freeze-dried hydrogel prepared from a colloidal suspension of chitosan and xanthan gum. The enzyme was successfully stabilized 
and released from the rehydrated samples at a moderate rate. Furthermore, the enzymatic activities of the encapsulated and released enzyme were confirmed for more than 30 days, which reinforces the potential of this technique for enzyme protection [139].

\subsection{Nanoprecipitation}

Nanoprecipitation is a simple and easy technique to reproduce, and it is commonly used to prepare nanoparticles [176]. This method is based on the interfacial deposition of a polymer following the displacement of a semi-polar solvent miscible with water from a lipophilic solution [177]. The process consists, initially, of the preparation of the solvent phase, normally composed of the film-forming polymer, one or more molecules to be encapsulated, a lipophilic surfactant, and one or more organic solvents, and the non-solvent phase, usually consisting of water. Subsequently, the two phases are mixed under moderate magnetic stirring, and the organic solvent is evaporated at room temperature or with a rotary evaporator, resulting in the nanoparticles being in an aqueous suspension. The water in the aqueous suspension containing the nanoparticles can be removed by ultracentrifugation or freeze-drying [176]. Figure $2 b$ shows a scheme to produce nanocapsules containing enzymes by the nanoprecipitation method.

Several polymers can be used in the encapsulation process by nanoprecipitation, emphasizing biodegradable polyesters such as polylactide, polylactide-co-glycolide, and poly-e-caprolactone. Likewise, several solvents have been used in this process, including ethanol, acetone, hexane, methylene chloride, or dioxane [176].

Markwalter et al. developed polymeric nanocarriers composed of poly (lactic acid) and poly (ethylene glycol) using the technique of inverse flash nanoprecipitation and demonstrated the wide applicability of the process, a large load capacity, and high reproducibility when encapsulating lysozyme and horseradish peroxidase [18]. Encapsulation retained $99 \%$ of enzyme activity after processing. Asparaginase was also encapsulated by nanoprecipitation in polyglycerol nanogels with an efficiency of almost 100\% [140]. Furthermore, no structural changes were observed after exposure to an acid environment to promote enzyme release, and the total enzymatic activity was maintained.

\subsection{Electrospinning}

Electrospinning is used to prepare continuous fibers on a sub-micron or nanometric scale through the action of an external electric field [178,179]. This process is carried out using a polymer or melted polymer solution, which is usually pumped using a syringe needle, to which a high voltage is applied [180]. The applied voltage induces a charge movement in the polymeric liquid, capable of stretching the droplet's shape, which normally is a sphere formed by the surface tension [180]. Once the electrostatic repulsion of the charged liquid polymer becomes greater than the surface tension, a conical shape known as Taylor's cone is formed, and the jet initiation begins at the tip of the cone [180]. If there is sufficient cohesive force in the polymer liquid, a stable stream is ejected from the Taylor cone, allowing the polymer chains to stretch together and form a uniform filament, which is deposited on a grounded metallic collector [180]. A typical electrospinning system is shown schematically in Figure 3.

Gabrielczyk et al. [141] evaluated the encapsulation performance of Bacillus subtilis fructosyltransferase by coaxial electrospinning using a set of biodegradable polymers and obtained an enzyme load of $68.1 \mathrm{mg} / \mathrm{g}$ and a specific enzyme activity of $5.5 \mathrm{U} / \mathrm{mg}$. An electrospun double-layer mucoadhesive patch was proposed by Edmans et al. [19] to deliver proteins to the oral mucosa. Lysozyme was incorporated into poly (vinylpyrrolidone)/Eudragit RS100 polymer nanofibers using electrospinning. A high encapsulation efficiency and preservation of enzyme activity were achieved (93.4\% and $96.1 \%$, respectively). 


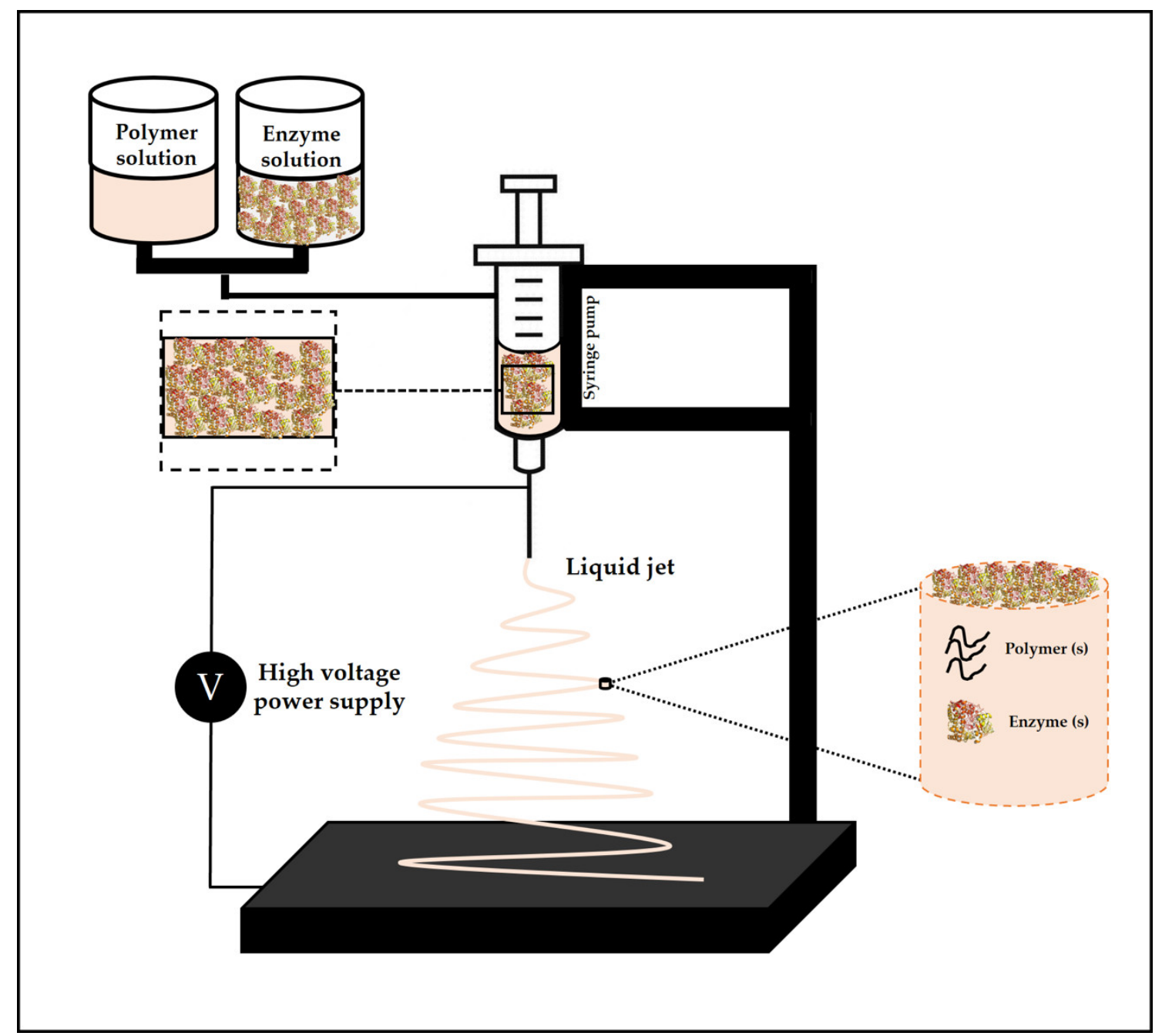

Figure 3. Basic diagram of the electrospinning process.

\section{Release Mechanisms for Encapsulated Enzymes}

Delivery systems are designed to release the active ingredients at a given site of action, at a controlled rate, or in response to a specific environmental trigger such as $\mathrm{pH}$, ionic strength, temperature, or enzyme activity [8]. In most applications of encapsulated enzymes, controlled release is essential to obtain the desired effect, as it guarantees a hydrolysis- or synthesis-controlled profile. Several release mechanisms have already been studied, and the most common are discussed below and represented in Figure 4.

Diffusion is the dominant mechanism in delivery systems [8], which consists of the random movement of the active molecules due to the existence of a chemical concentration gradient [181]. The rate at which the active ingredient is released during the diffusive process depends on many factors, including solute properties (such as molecular weight and polarity), matrix properties (such as polarity, rheology, physical state, and interactions), characteristics of the microparticle (such as size, shape, and structure), and the gradient of solute concentration between the particle and the surrounding environment. Moreover, the encapsulating system may be stable throughout diffusion or undergo changes due to events of swelling, shrinkage, erosion, and fragmentation [8]. 


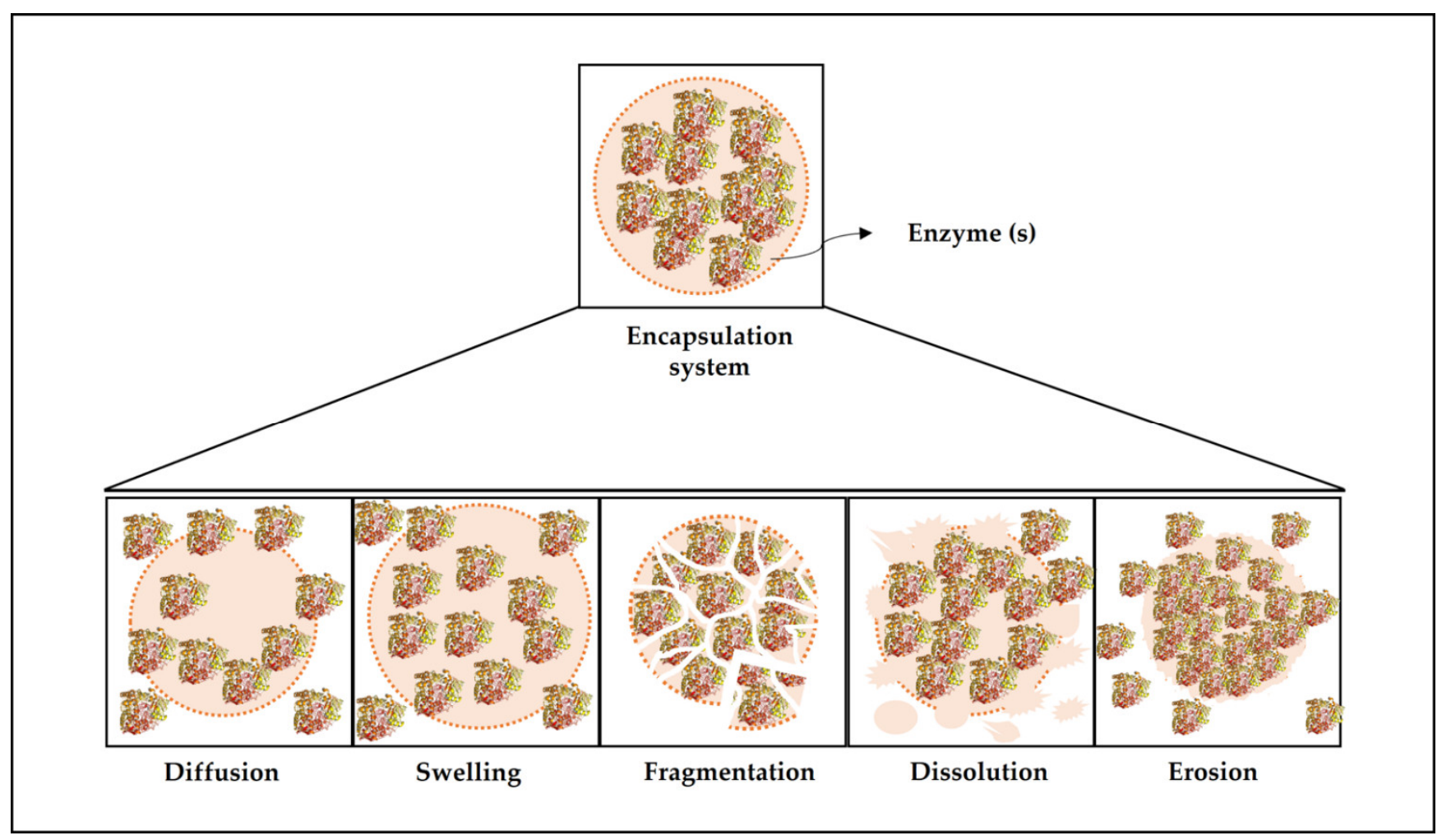

Figure 4. Different mechanisms of enzyme release from polymeric matrices.

Release by the swelling mechanism is also quite common. In this mechanism, the active ingredient is released from the particles when they absorb the solvent from the surrounding medium (usually water) and swell, increasing the pores' size. The release rate of the active ingredient will depend on the swelling rate and the time it takes the active ingredients to diffuse through the swollen microparticle matrix. [8]. The swelling release can be controlled by selecting the appropriate polymeric matrix, as well as the conditions of the surrounding environment, including temperature and $\mathrm{pH}$ [9]. The release can also occur by fragmentation, when the microstructure breaks due to external conditions, such as mechanical pressure, shear, $\mathrm{pH}$ changes, and others [9]. The release rate in this mechanism depends on the fracture properties of the particle and the size and shape of the fragments formed. Normally, the release by this mechanism is rapid due to the increase in surface area and the influence of other release mechanisms, such as diffusion, dissolution, and erosion [8].

There are also encapsulation systems that use the dissolution release mechanism, considered one of the simplest designs [182]. Release by this mechanism occurs when the encapsulating system is placed under conditions that lead to the dissolution of the microstructure. The microstructure can be completely constituted by the active molecule, releasing the product as the particle dissolves, or it may consist of a polymeric matrix containing the dispersed active material, in which the release occurs by the dissolution of that matrix [8]. The release rate by this mechanism is directly correlated to the dissolution rate, which depends on the microparticle's composition and structure and external factors, such as $\mathrm{pH}$, solvent type, ionic strength, and temperature [8]. Finally, delivery can also occur through the erosion mechanism, which consists of the erosion of the microparticle matrix due to physical factors, such as temperature; chemicals, such as strong acids or bases; and enzymes, such as lipases and amylases. The erosion process can occur superficially or fully, and the release profile is directly related to the erosion rate. The greater the erosion, the greater the release rates of the encapsulated molecules [8,9].

Babich et al. [156] evaluated the release of L-phenylalanine ammonia-lyase encapsulated in simulated fluids and observed that, in distilled water, the degree of degradation 
of the capsules containing the enzyme reached $55-65 \%$ after $120 \mathrm{~min}$. The maximum degradations of the microcapsules (90-98\%) occurred in a bio-relevant media model simulating intestinal juice. Osman et al. [16] evaluated the in vitro release of DNase I from a microparticle system to treat cystic fibrosis via the pulmonary route and observed that for microparticles without surface modification, about $24 \%$ of the enzyme was released during the first $6 \mathrm{~h}$. The inclusion of the hydrophilic surface modifiers increased this amount to varying degrees, which corresponds to the DNase I located on the surface of the particles.

The release rate of firefly luciferase encapsulated in the freeze-dried hydrogel of chitosan and xanthan gum was investigated using a standard leaching (erosion) test. The enzyme release rate was higher at $\mathrm{pH}$ 6.0, and the addition of montmorillonite nanoclay significantly reduced the rate of enzyme release due to the strong influence on the structural modification of the bionanocomposites [139]. Anjani et al. [14] evaluated the in vitro release rate of flavourzyme by the dissolution mechanism using a trisodium citrate buffer at different concentrations $(0.5-2.0 \%)$. The authors found that the release rate increased with an increment in buffer concentration from 0.5 to $2.0 \%$.

\section{Characterization of Encapsulation Systems}

The characterization of microparticles is crucial in the overall encapsulation process because it provides important information for process optimization. The main techniques used to characterize encapsulation systems developed for the trapping of enzymes are usually aimed at evaluating the yield and efficiency of encapsulation, morphological characteristics, and physical aspects [13].

Yield and efficiency encapsulation are variables that are related to the quantification of the active molecule incorporated in the microstructures. These parameters can be established by analytical methods, such as UV-visible spectrophotometry, high-performance liquid chromatography (HPLC), or gas chromatography (GC) [177]. The determination of yield and encapsulation efficiency is essential in enzyme trapping because the encapsulation yield may not positively correlate with the encapsulation efficiency, that is, obtaining a high encapsulation yield may not provide a high encapsulation efficiency. This is because the encapsulation efficiency is linked to the concentration of active molecules after the encapsulation process, which does not occur for the encapsulation yield, which is associated with the total concentration of the molecule (active or inactive). These facts can be observed in the study developed by Pereira et al. [57]. They found a high encapsulation yield for Yarrowia lipolytica lipase ( $>90 \%$ ) in an alginate and chitosan matrix but noted that the enzyme activity was low in some cases (low encapsulation efficiency).

The characterization of the particles produced in terms of surface size and morphology is also quite relevant. Scanning electron microscopy (SEM), transmission electron microscopy (TEM), and dynamic light scattering (DLS) are the techniques most used for this purpose $[183,184]$. Pereira et al. [13] used SEM to evaluate the morphology of microcapsules containing Yarrowia lipolytica lipase obtained by the ion gelation technique and observed a collapsed and heterogeneous surface after drying by freeze-drying. This observation was necessary for the authors to understand the significant increase in enzyme activity after the drying process was attributed to the increase in the surface area.

The evaluation of the physical characteristics of the microparticles are also crucial, and the main ones are zeta potential, thermal gravimetric analysis (TGA), differential thermal analysis (DTA), differential scanning calorimetry (DSC), Fourier transform infrared spectroscopy (FTIR), and X-ray diffraction. Zeta potential determines the surface electrical charge of the microparticles and is of great importance in assessing their stability and behavior in a biological environment $[13,177]$. TGA, DTA, and DSC are thermodynamic characterizations that provide important information about the properties of the chemical compounds that form the microparticles. TGA uses heat to force reactions and physical changes in materials and generate thermogravimetric curves that characterize specific compounds due to the unique sequence of physical-chemical reactions. DTA is based on the principle that the substance, when heated, undergoes reactions and phase changes that 
involve absorption or heat emission, with the identification of a substance being performed by comparing the DTA curves obtained from the unknown substance with the DTA curves that are provided by elements [177].

On the other hand, DSC is based on the release of heat from a chemical process, which is determined by the variation of enthalpy [185]. Another important analysis in the physical characterization of the microparticles is the FTIR. This analysis is used to evaluate the possible chemical interactions between polymers and biomolecules. Finally, another analysis of equal importance is X-ray diffraction, normally used to verify the crystalline and amorphous regions of the microparticles [13].

\section{Factors Influencing Active Molecules Encapsulation Efficiency}

Different parameters can affect the rate of solidification of microparticles, directly influencing the encapsulation efficiency. The encapsulating system must ensure the delivery of enzymes in their native folding state and structure so that their biological activity is sustained [186]. Nevertheless, the encapsulating process' success depends on the characteristics of coating materials and the stability of active compounds in the core, along with the adequacy of the delivery system for its application [187].

Encapsulation efficiency can increase as the polymer concentration rises once the high concentration induces fast precipitation of the polymer on the surface of the dispersed phase, retarding the active molecule diffusion. Moreover, when diffusional resistance to encapsulated material from the organic phase to the aqueous phase is high, more active molecules are entrapped, raising particle size [188]. The viscosity of the solution increases when it is highly concentrated, also leading to encapsulating material dispersion delay. In addition, high viscosity and rapid solidification of the dispersed phase can diminish the microparticles' porosity and consequently improve the encapsulating efficiency [189].

Srikar and Rani [17] indicated that the molecular weight of the polymer was directly proportional to the entrapment efficiency. For polymers that display high viscosity, the active molecule are encapsulated longer than in the presence of low molecular weight polymers. Encapsulation efficiency can fall within a certain particle size range, and the active molecule release rate can accelerate if the particle size is reduced. It was also observed that particle size can decrease when the organic phase's concentration increases once the viscosity of the solution rises [189].

Polymer hydrophobicity can also influence the entrapment efficiency since the encapsulating material is highly hydrophobic; it hampers the encapsulated active molecule's escape to the aqueous phase, achieving a low efficiency [190]. The opposite is observed when the entrapped molecule presents higher solubility in the continuous phase than in the dispersed phase, leading to an easy diffusion and good encapsulation efficiency [189].

Another factor influencing the encapsulation efficiency is the ratio of dispersed phase to continuous phase $(\mathrm{D} / \mathrm{C}$ ratio). When the $\mathrm{D} / \mathrm{C}$ ratio decreases, it was observed that active molecule loading and encapsulation efficiency increased and the microsphere surface was smoother, perhaps because of a faster solidification rate. The porosity in a system of microspheres can be established during encapsulating polymer hardening when the organic solvent evaporates during preparation. If a continuous phase contains a large amount of water, the polymer will precipitate faster, and consequently, less porous spheres will be formed. Additionally, it was reported that as the volume of the continuous phase rises, the size of microspheres reduces, promoting a decrease in loading efficiency and a faster molecule release [18].

Considering the interaction between polymer and active molecules, encapsulation efficiency can increase when molecules as proteins interact with polymers carrying free carboxylic end groups compared to end-capped ones. This occurs if electrostatic interactions are involved in the encapsulation process. However, protein release from the microparticles can be limited if the interaction is too strong. As an alternative, a co-encapsulated excipient can intermediate the interaction between the protein and polymer $[186,189]$. 


\section{Applications of Polymer Encapsulated Enzymes}

Encapsulated enzymes can be used for several different purposes, and therefore can find applications in a wide range of industrial sectors. Some examples that show pharmaceutical, medical, and food applications are depicted in Table 2. Despite the recent articles showing the use of encapsulating enzymes in biocatalysis [13,141], this use is not so intense because of the low reuse efficiency and reduced mass transfer. Pereira et al. [13] reported that p-nitrophenyl laurate hydrolysis by lipase encapsulated in chitosan-alginate beads decreased by $52 \%$ in the second reaction cycle and indicated a reduction of reaction rate, which might be due to substrate or product retained in the active site.

Table 2. Application of polymer encapsulated enzymes.

\begin{tabular}{|c|c|c|c|}
\hline Enzyme & Method & Application & Refs. \\
\hline Lysozyme & Electrospinning & $\begin{array}{l}\text { Drug delivery/delivery of } \\
\text { biopharmaceuticals to the oral mucosa. }\end{array}$ & [19] \\
\hline$\beta$-galactosidase & Electrospinning & Oral drug delivery. & [152] \\
\hline Fructosyltransferase & Electrospinning & Biocatalysts. & [141] \\
\hline Papain & Electrospinning & Wound debridement. & [190] \\
\hline Phosphatase & Freeze-drying & Reaction engineering. & [17] \\
\hline Bromelain & Freeze-drying/ionic gelation & $\begin{array}{l}\text { Wound healing and blood circulation } \\
\text { improvement. }\end{array}$ & [138] \\
\hline L-asparaginase & Ionic gelation & Drug release. & [167] \\
\hline Pectinase & Ionic gelation & Clarifying orange juice. & [163] \\
\hline Flavourzyme & Ionic gelation & Cheese ripening. & [14] \\
\hline Aminopeptidase & Ionic gelation & $\begin{array}{l}\text { Food industry: accelerating; cheddar cheese } \\
\text { ripening through peptide hydrolysis. }\end{array}$ & [191] \\
\hline $\begin{array}{c}\text { Lysozyme; } \\
\alpha \text {-chymotrypsin }\end{array}$ & Nanoprecipitation & $\begin{array}{l}\text { Novel treatments in immunology, oncology, } \\
\text { or enzyme therapies. }\end{array}$ & [154] \\
\hline DNAse 1 & Spray-drying & $\begin{array}{l}\text { Delivery of particulates carrying therapeutics } \\
\text { to patients with cystic fibrosis. }\end{array}$ & [16] \\
\hline
\end{tabular}

Drug delivery strategies that can be achieved with encapsulating enzymes are significantly advantageous for pharmaceutical and medical applications because they can direct the enzyme to the right location. Edmans et al. [19] incorporated lysozyme into poly (vinylpyrrolidone)/Eudragit RS100 polymer nanofibers using electrospinning from an ethanol/water mixture as an antimicrobial protein to the oral mucosa. The resulting fibrous membranes released the protein at a clinically desirable rate $(90 \%$ cumulative release after $2 \mathrm{~h}$ ) and inhibited the growth of the oral bacterium Streptococcus ratti, showing its potential to treat and prevent oral infections. Vimal and Kumar [167] reported that the antimicrobial property of L-asparaginase increased when it was encapsulated inside a chitosan nanoparticle, demonstrating that the enzyme nano-carrier has better therapeutic potential as compared to the free enzyme. Osman et al. [16] tested various hydrophilic excipients to produce controlled release microparticles by co-spray drying DNase I with poly (lactic-co-glycolic) acid and 1,2-dipalmitoyl-Sn-phosphatidyl choline (biocompatible surfactant). These microparticles prepared with dextran were biocompatible with lung epithelial cells and showed a controlled release to reduce cystic fibrosis mucus viscosity.

The incorporation of enzymes into food products can also be achieved with encapsulation strategies. Anjani et al. [14] used flavourzyme encapsulated with alginate for cheese ripening. The enzyme leakage from capsules increased with an increase in the duration of the simulated cheese press from 4 to $16 \mathrm{~h}$, but the control of the amount of enzyme leakage is still needed to direct the proteolysis required for optimal flavor development in accelerated cheese ripening. Microbial pectinase encapsulated by sodium alginate was used successfully by Mahmoud et al. [163] to eliminate pectin from orange juice, reducing turbidity since the free enzyme cannot be used in this case due to the high acidity of the juice. 
Another possible application of encapsulated enzymes is for polymerase chain reaction (PCR), which is an extensively used technique to amplify DNA in vitro. Due to the limitation of parallel reactions by the conventional methodology, major screening studies are restricted. Mak et al. [192] proposed the use of diffusion controlled and temperature stable microcapsule compartments to perform a high number of individual PCRs. The authors demonstrated that a great number of individual PCRs confined in microcapsules containing Taq DNA polymerase can occur in a single reaction tube since low molecular reactants are allowed to diffuse in the permeability controlled capsules.

RNA is a biomolecule with a wide range of important cellular functions, such as information storage, catalysis, and regulation, and can also benefit from encapsulation considering its susceptibility to degradation. RNA was successfully synthesized and internalized in polymer hydrogel capsules containing T7 RNA polymerase, leading to minimization of molecule handling and bypassing isolation and purification paths [193,194]. Figure 5 illustrates some possible applications of encapsulated enzymes.
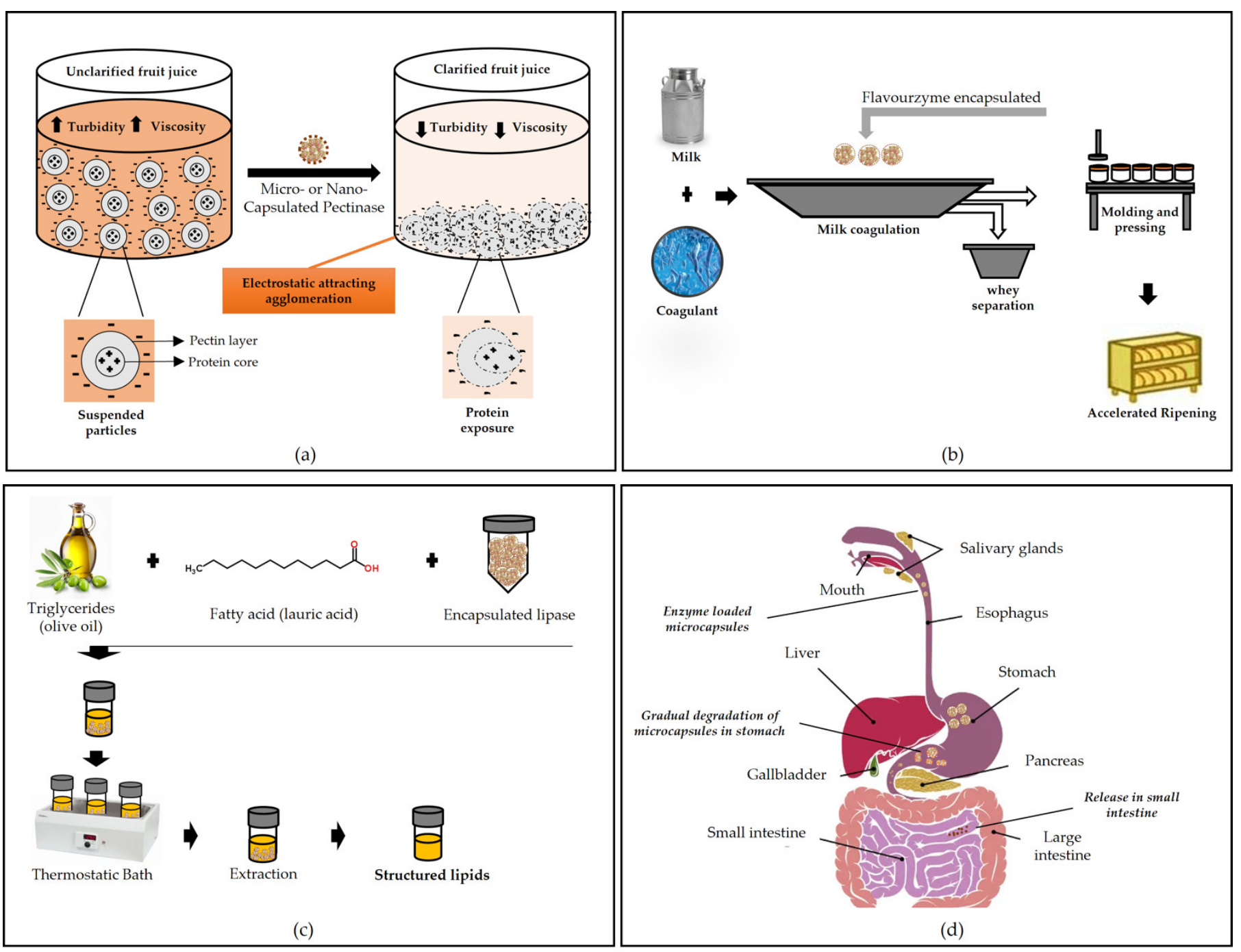

Figure 5. Application of microcapsules containing enzymes: (a) juice clarification, (b) cheese maturation, (c) biocatalysis of structured lipids, and (d) oral drug delivery. 


\section{Conclusions and Future Perspectives}

When using enzymes, we are faced with one huge problem: their stability. The stability of enzymes is linked to interactions formed in their structure, which can be easily destabilized when placed in adverse environmental conditions, such as variations in temperature, $\mathrm{pH}$, or ionic strength. Therefore, delivery systems, such as encapsulation with polymers, are an alternative way to protect the catalytic activity of enzymes until they reach the target site, where they will be released, or during their use in a reaction system. Ionic gelation, spray drying, freeze-drying, nanoprecipitation, and electrospinning are the main techniques reported for the development of enzyme delivery systems. The use of these transporters has shown great benefits in improving enzymatic stability, which increases the possibility of using these biomolecules in industry. However, only a few polymers have been tested so far, which shows that new options can be studied in future research. Other methods such as coacervation, double emulsion, and polymerization have been tested successfully in a few studies and should also be the targets of new insights. The development of new polymeric structures for the encapsulation of enzymes, aiming at their application and reuse in catalytic systems, should also be explored. The information covered in this review provides guidance for the future development of more advanced transport systems for application in enzyme encapsulation.

Author Contributions: Conceptualization, A.d.S.P. and P.F.F.A.; methodology, A.d.S.P., C.P.L.S., L.M., G.C.F.-S. and P.F.F.A.; software, A.d.S.P., C.P.L.S., L.M., G.C.F.-S. and P.F.F.A.; validation, A.d.S.P., C.P.L.S., L.M., G.C.F.-S. and P.F.F.A.; formal analysis, A.d.S.P., C.P.L.S., L.M., G.C.F.-S. and P.F.F.A.; investigation, A.d.S.P., C.P.L.S., L.M., G.C.F.-S. and P.F.F.A.; resources, A.d.S.P., C.P.L.S., L.M., G.C.F.S. and P.F.F.A.; writing-original draft preparation, A.d.S.P., C.P.L.S., L.M., G.C.F.-S. and P.F.F.A.; writing-review and editing, A.d.S.P. and P.F.F.A.; visualization, A.d.S.P., C.P.L.S., L.M., G.C.F.-S. and P.F.F.A.; supervision, A.d.S.P. and P.F.F.A.; project administration, A.d.S.P. and P.F.F.A.; funding acquisition, A.d.S.P. and P.F.F.A. All authors have read and agreed to the published version of the manuscript.

Funding: This study was supported by Fundação Carlos Chagas Filho de Amparo à Pesquisa do Estado do Rio de Janeiro (FAPERJ—grant number E-26/201.915/2020), Coordenação de Aperfeiçoamento de Pessoal de Nível Superior (Bolsa D.Sc.), and Conselho Nacional de Desenvolvimento Científico e Tecnológico (CNPq-Bolsa PQ: 308626/2019-2).

Institutional Review Board Statement: Not applicable.

Informed Consent Statement: Not applicable.

Conflicts of Interest: The authors declare no conflict of interest. The funders had no role in the design of the study; in the collection, analyses, or interpretation of data; in the writing of the manuscript, or in the decision to publish the results.

\section{References}

1. Kirk, O.; Borchert, T.V.; Fuglsang, C.C. Industrial Enzyme Applications. Curr. Opin. Biotechnol. 2002, 13, 345-351. [CrossRef]

2. Fraga, J.L.; Souza, C.P.L.; da S. Pereira, A.; Aguieiras, E.C.G.; de Silva, L.O.; Torres, A.G.; Freire, D.G.; Amaral, P.F.F. Palm Oil Wastes as Feedstock for Lipase Production by Yarrowia lipolytica and Biocatalyst Application/Reuse. 3 Biotech 2021, $11,191$. [CrossRef]

3. Nunes, P.M.B.; Fraga, J.L.; Ratier, R.B.; Rocha-Leão, M.H.M.; Brígida, A.I.S.; Fickers, P.; Amaral, P.F.F. Waste Soybean Frying Oil for the Production, Extraction, and Characterization of Cell-Wall-Associated Lipases from Yarrowia lipolytica. Bioprocess Biosyst. Eng. 2021, 44, 809-818. [CrossRef] [PubMed]

4. Da Pereira, S.A.; Fontes-Sant'Ana, G.C.; Amaral, P.F.F. Mango Agro-Industrial Wastes for Lipase Production from Yarrowia Lipolytica and the Potential of the Fermented Solid as a Biocatalyst. Food Bioprod. Process. 2019, 115, 68-77. [CrossRef]

5. Bornscheuer, U.T.; Huisman, G.W.; Kazlauskas, R.J.; Lutz, S.; Moore, J.C.; Robins, K. Engineering the Third Wave of Biocatalysis. Nature 2012, 485, 185-194. [CrossRef]

6. Bornscheuer, U.T.; Pohl, M. Improved Biocatalysts by Directed Evolution and Rational Protein Design. Curr. Opin. Chem. Biol. 2001, 5, 137-143. [CrossRef]

7. Basso, A.; Serban, S. Industrial Applications of Immobilized Enzymes-A Review. Mol. Catal. 2019, 479, 6437-6474. [CrossRef]

8. McClements, D.J. Nanoparticle- and Microparticle-Based Delivery Systems: Encapsulation, 1st ed.; CRC Press: Boca Ratón, FL, USA, 2015. 
9. Boostani, S.; Jafari, S.M. Controlled release of nanoencapsulated food ingredients. In Release and Bioavailability of Nanoencapsulated Food Ingredients; Elsevier: Amsterdam, The Netherlands, 2020; pp. 27-78.

10. Sheldon, R.A.; van Pelt, S. Enzyme Immobilisation in Biocatalysis: Why, What and How. Chem. Soc. Rev. 2013, 42, 6223-6235. [CrossRef] [PubMed]

11. Mohamad, N.R.; Marzuki, N.H.C.; Buang, N.A.; Huyop, F.; Wahab, R.A. An Overview of Technologies for Immobilization of Enzymes and Surface Analysis Techniques for Immobilized Enzymes. Biotechnol. Biotechnol. Equip. 2015, 29, 205-220. [CrossRef] [PubMed]

12. Tran, D.N.; Balkus, K.J., Jr. Perspective of Recent Progress in Immobilization of Enzymes. ACS Catal. 2011, 1, 956-968. [CrossRef]

13. da S. Pereira, A.; Diniz, M.M.; de Jong, G.; Gama Filho, H.S.; dos Anjos, M.J.; Finotelli, P.V.; Fontes-Sant'Ana, G.C.; Amaral, P.F.F Chitosan-Alginate Beads as Encapsulating Agents for Yarrowia Lipolytica Lipase: Morphological, Physico-Chemical and Kinetic Characteristics. Int. J. Biol. Macromol. 2019, 139, 621-630. [CrossRef]

14. Anjani, K.; Kailasapathy, K.; Phillips, M. Microencapsulation of Enzymes for Potential Application in Acceleration of Cheese Ripening. Int. Dairy J. 2007, 17, 79-86. [CrossRef]

15. Nguyen, H.H.; Kim, M. An Overview of Techniques in Enzyme Immobilization. Appl. Sci. Converg. Technol. 2017, 26, 157-163. [CrossRef]

16. Osman, R.; al Jamal, K.T.; Kan, P.L.; Awad, G.; Mortada, N.; EL-Shamy, A.E.; Alpar, O. Inhalable DNase I Microparticles Engineered with Biologically Active Excipients. Pulm. Pharmacol. Ther. 2013, 26, 700-709. [CrossRef]

17. Chivers, P.R.A.; Kelly, J.A.; Hill, M.J.S.; Smith, D.K. First-Generation Shaped Gel Reactors Based on Photo-Patterned Hybrid Hydrogels. React. Chem. Eng. 2020, 5, 1112-1117. [CrossRef]

18. Markwalter, C.E.; Pagels, R.F.; Hejazi, A.N.; Gordon, A.G.R.; Thompson, A.L.; Prud'homme, R.K. Polymeric Nanocarrier Formulations of Biologics Using Inverse Flash NanoPrecipitation. AAPS J. 2020, 22, 1-16. [CrossRef] [PubMed]

19. Edmans, J.G.; Murdoch, C.; Santocildes-Romero, M.E.; Hatton, P.V.; Colley, H.E.; Spain, S.G. Incorporation of Lysozyme into a Mucoadhesive Electrospun Patch for Rapid Protein Delivery to the Oral Mucosa. Mater. Sci. Eng. C 2020, 112, 110917. [CrossRef] [PubMed]

20. Boudrant, J.; Woodley, J.M.; Fernandez-Lafuente, R. Parameters Necessary to Define an Immobilized Enzyme Preparation. Process. Biochem. 2020, 90, 66-80. [CrossRef]

21. Jenkins, A.D.; Kratochvíl, P.; Stepto, F.T.; Suter, U.W. Glossary of Basic Terms in Polymer Science (IUPAC Recommendations 1996). Pure Appl. Chem. 1996, 68, 2287-2311. [CrossRef]

22. Yadav, V.; Sharma, A.; Singh, S.K. Microencapsulation Techniques Applicable To Food Flavours Research And Development: A Comprehensive Review. Int. J. Food Nutr. Sci. 2015, 4, 119-124.

23. Abbasian, M.; Massoumi, B.; Mohammad-Rezaei, R.; Samadian, H.; Jaymand, M. Scaffolding Polymeric Biomaterials: Are Naturally Occurring Biological Macromolecules More Appropriate for Tissue Engineering? Int. J. Biol. Macromol. 2019, 134, 673-694. [CrossRef] [PubMed]

24. Ogueri, K.S.; Jafari, T.; Escobar Ivirico, J.L.; Laurencin, C.T. Polymeric Biomaterials For Scaffold-Based Bone Regenerative Engineering. Regen. Eng. Transl. Med. 2019, 5, 128-154. [CrossRef] [PubMed]

25. Reddy, M.S.B.; Ponnamma, D.; Choudhary, R.; Sadasivuni, K.K. A Comparative Review of Natural and Synthetic Biopolymer Composite Scaffolds. Polymers 2021, 13, 1105. [CrossRef] [PubMed]

26. Rabanel, J.M.; Banquy, X.; Zouaoui, H.; Mokhtar, M.; Hildgen, P. Progress Technology in Microencapsulation Methods for Cell Therapy. Biotechnol. Prog. 2009, 25, 946-963. [CrossRef]

27. Anderson, D.G.; Langer, R.S.; Dang, T.T. Hydrogel Encapsulated Cells And Anti-Inflammatory Drugs. U.S. Patent 9,867,781, 16 January 2018.

28. Cascone, M.G.; Barbani, N.; Cristallini, C.; Giusti, P.; Ciardelli, G.; Lazzeri, L. Bioartificial Polymeric Materials Based on Polysaccharides. J. Biomater. Sci. Polym. Ed. 2001, 12, 267-281. [CrossRef]

29. Zaharaki, D.; Komnitsas, K.; Perdikatsis, V. Use of Analytical Techniques for Identification of Inorganic Polymer Gel Composition. J. Mater. Sci. 2010, 45, 2715-2724. [CrossRef]

30. Wang, C.; Gu, P.; Hu, B.; Zhang, Q. Recent Progress in Organic Resistance Memory with Small Molecules and Inorganic-Organic Hybrid Polymers as Active Elements. J. Mater. Chem. C 2015, 3, 10055-10065. [CrossRef]

31. Mahajan, A.; Aggarwal, G. Smart Polymers: Innovations In Novel Drug Delivery. Int. J. Drug Dev. Res. 2011, 3, 16-30.

32. Ma, Q.; Gao, X.; Bi, X.; Han, Q.; Tu, L.; Yang, Y.; Shen, Y.; Wang, M. Dissolution and Deacetylation of Chitin in Ionic Liquid Tetrabutylammonium Hydroxide and Its Cascade Reaction in Enzyme Treatment for Chitin Recycling. Carbohydr. Polym. 2020, 230, 115605. [CrossRef] [PubMed]

33. Raza, Z.A.; Khalil, S.; Ayub, A.; Banat, I.M. Recent Developments in Chitosan Encapsulation of Various Active Ingredients for Multifunctional Applications. Carbohydr. Res. 2020, 492, 108004. [CrossRef] [PubMed]

34. Freitas, A.K.C.; da Silva, L.B.; da Costa, A.C.S.; Peres, A.P.S.; Pergher, S.B.C.; Acchar, W. Tricalcium Phosphate Sheets with Chitosan Obtained via Aqueous Tape Casting. Cerâmica 2020, 66, 421-425. [CrossRef]

35. Cheung, R.C.F.; Ng, T.B.; Wong, J.H.; Chan, W.Y. Chitosan: An Update on Potential Biomedical and Pharmaceutical Applications. Mar. Drugs 2015, 13, 5156. [CrossRef] [PubMed] 
36. Brumano, L.P.; da Silva, F.V.S.; Costa-Silva, T.A.; Apolinário, A.C.; Santos, J.H.P.M.; Kleingesinds, E.K.; Monteiro, G.; Rangel-Yagui, C.O.; Benyahia, B.; Junior, A.P. Development of L-Asparaginase Biobetters: Current Research Status and Review of the Desirable Quality Profiles. Front. Bioeng. Biotechnol. 2019, 6, 212. [CrossRef]

37. Racine, E.; Sattler, S.; Escande, A. Free Will and the Brain Disease Model of Addiction: The Not So Seductive Allure of Neuroscience and Its Modest Impact on the Attribution of Free Will to People with an Addiction. Front. Psychol. 2017, 8, 1850. [CrossRef]

38. Sacco, P.; Furlani, F.; de Marzo, G.; Marsich, E.; Paoletti, S.; Donati, I. Concepts for Developing Physical Gels of Chitosan and of Chitosan Derivatives. Gels 2018, 4, 67. [CrossRef]

39. Bezerra, C.S.; de Lemos, F.C.M.G.; de Sousa, M.; Gonçalves, L.R.B. Enzyme Immobilization onto Renewable Polymeric Matrixes: Past, Present, and Future Trends. J. Appl. Polym. Sci. 2015, 132, 42125. [CrossRef]

40. Cardoso, F.D.S.N.; Koblitz, M.G.B.; Ortiz, G.M.D.; Carvalho, J.L.V.D.; Carvalho, L.M.J.d. Study of the Parameters Used in the Encapsulation of Commercial Pectinase in Calcium Alginate and Its Effect on Its Catalytic Activity. Food Sci. Technol. 2019, 39, 247-252. [CrossRef]

41. Miao, T.; Wang, J.; Zeng, Y.; Liu, G.; Chen, X. Polysaccharide-Based Controlled Release Systems for Therapeutics Delivery and Tissue Engineering: From Bench to Bedside. Adv. Sci. 2018, 5, 1700513. [CrossRef]

42. Debele, T.A.; Mekuria, S.L.; Tsai, H.C. Polysaccharide based nanogels in the drug delivery system: Application as the carrier of pharmaceutical agents. Mater. Sci. Eng. C 2016, 68, 964-981. [CrossRef]

43. Guo, X.; Wang, Y.; Qin, Y.; Shen, P.; Peng, Q. Structures, Properties and Application of Alginic Acid: A Review. Int. J. Biol. Macromol. 2020, 162, 618-628. [CrossRef] [PubMed]

44. Grace, K.; Arjun, N.; Shu-Meng, K.; Rahul, K.; So-Ra, L.; Michael, A.; Paul, D.V.; Elliot, B.; Jonathan, L. Alginate Composition, Temperature, and Presence of Islet Tissue Influence Microcapsule Permeability. Front. Bioeng. Biotechnol. 2016, 4. [CrossRef]

45. Tønnesen, H.H.; Karlsen, J. Alginate in Drug Delivery Systems. Drug Dev. Ind. Pharm. 2002, 28, 837-854. [CrossRef]

46. Lee, K.Y.; Mooney, D.J. Alginate: Properties and Biomedical Applications. Prog. Polym. Sci. 2012, 37, 106-126. [CrossRef]

47. Moriyama, J.; Yoshimoto, M. Efficient Entrapment of Carbonic Anhydrase in Alginate Hydrogels Using Liposomes for ContinuousFlow Catalytic Reactions. ACS Omega 2021, 6, 6368-6378. [CrossRef]

48. Shahid, F.; Aman, A.; Ul Qader, S.A. Immobilization of Dextranase Using Anionic Natural Polymer Alginate as a Matrix for the Degradation of a Long-Chain Biopolymer (Dextran). Int. J. Polym. Sci. 2019, 2019, 1354872. [CrossRef]

49. Sankalia, M.G.; Mashru, R.C.; Sankalia, J.M.; Sutariya, V.B. Stability Improvement of Alpha-Amylase Entrapped in KappaCarrageenan Beads: Physicochemical Characterization and Optimization Using Composite Index. Int. J. Pharm. 2006, $312,1-14$. [CrossRef] [PubMed]

50. Sankalia, M.G.; Mashru, R.C.; Sankalia, J.M.; Sutariya, V.B. Physicochemical Characterization of Papain Entrapped in Ionotropically Cross-Linked Kappa-Carrageenan Gel Beads for Stability Improvement Using Doehlert Shell Design. J. Pharm. Sci. 2006, 95, 1994-2013. [CrossRef] [PubMed]

51. Dey, G.; Bhupinder, S.; Banerjee, R. Immobilization of Alpha-Amylase Produced by Bacillus Circulans GRS 313. Braz. Arch. Biol. Technol. 2003, 46, 167-176. [CrossRef]

52. Won, K.; Kim, S.; Kim, K.J.; Park, H.W.; Moon, S.J. Optimization of Lipase Entrapment in Ca-Alginate Gel Beads. Process Biochem. 2005, 40, 2149-2154. [CrossRef]

53. Konsoula, Z.; Liakopoulou-Kyriakides, M. Thermostable $\alpha$-Amylase Production by Bacillus Subtilis Entrapped in Calcium Alginate Gel Capsules. Enzym. Microb. Technol. 2006, 39, 690-696. [CrossRef]

54. Konsoula, Z.; Liakopoulou-Kyriakides, M. Starch Hydrolysis by the Action of an Entrapped in Alginate Capsules $\alpha$-Amylase from Bacillus Subtilis. Process. Biochem. 2006, 41, 343-349. [CrossRef]

55. Demirkan, E.; Dincbas, S.; Sevinc, N.; Ertan, F. Immobilization of B. Amyloliquefaciens $\alpha$-Amylase and Comparison of Some of Its Enzymatic Properties with the Free Form. Rom. Biotechnol. Lett. 2011, 16, 6690-6701.

56. Peña-Montes, C.; Mondragón-Tintor, M.E.; Castro-Rodríguez, J.A.; Bustos-Jaimes, I.; Navarro-Ocaña, A.; Farrés, A. Immobilization and biochemical properties of the enantioselective recombinant NStcI esterase of Aspergillus nidulans. Enzym. Res. 2013, 2013, 928913. [CrossRef]

57. Pereira, A.d.S.; Fraga, J.L.; Diniz, M.M.; Fontes-Sant'ana, G.C.; Amaral, P.F.F. High Catalytic Activity of Lipase from Yarrowia Lipolytica Immobilized by Microencapsulation. Int. J. Mol. Sci. 2018, 19, 3393. [CrossRef] [PubMed]

58. Zusfahair, D.R.N.; Kartika, D.; Kurniasih, M.; Nofiani, R.; Fatoni, A. Improved Reuse and Affinity of Enzyme Using Immobilized Amylase on Alginate Matrix. J. Phys. Conf. Ser. 2020, 1494, 012028. [CrossRef]

59. DeGroot, A.R.; Neufeld, R.J. Encapsulation of Urease in Alginate Beads and Protection from $\alpha$-Chymotrypsin with Chitosan Membranes. Enzym. Microb. Technol. 2001, 29, 321-327. [CrossRef]

60. Hosseini, S.; Varidi, M. Optimization of Microbial Rennet Encapsulation in Alginate-Chitosan Nanoparticles. Food Chem. 2021, 352, 129325. [CrossRef]

61. Gür, S.; İdil, N.; Aksöz, N. Optimization of Enzyme Co-Immobilization with Sodium Alginate and Glutaraldehyde-Activated Chitosan Beads. Appl. Biochem. Biotechnol. 2018, 184, 538-552. [CrossRef]

62. Rezakhani, N.; Molaei rad, A.; Parivar, K.; Khayat, M.; Etemadzade, S. Immobilization of Protease in Biopolymers (Mixture of Alginate-Chitosan). J. Paramed. Sci. 2014, 5, 108-113.

63. Raghu, S.; Biol, T.J.; Pennathur, G. Enhancing the Stability of a Carboxylesterase by Entrapment in Chitosan Coated Alginate Beads. Turk. J. Biol. 2018, 42, 307-318. [CrossRef] 
64. Adzmi, F.; Meon, S.; Musa, M.H.; Yusuf, N.A. Preparation, characterisation and viability of encapsulated Trichoderma harzianum UPM40 in alginate-montmorillonite clay. J. Microencapsul. 2012, 29, 205-210. [CrossRef]

65. Rahim, S.N.A.; Sulaiman, A.; Hamzah, F.; Hamid, K.H.K.; Rodhi, M.N.M.; Musa, M.; Edama, N.A. Enzymes Encapsulation within Calcium Alginate-Clay Beads: Characterization and Application for Cassava Slurry Saccharification. Procedia Eng. 2013, 68, 411-417. [CrossRef]

66. Freitas, F.F.; Marquez, L.D.S.; Ribeiro, G.P.; Brandão, G.C.; Cardoso, V.L.; Ribeiro, E.J. Optimization of the Immobilization Process of $\beta$-Galatosidade by Combined Entrapment-Cross-Linking and the Kinetics of Lactose Hydrolysis. Braz. J. Chem. Eng. 2012, 29, 15-24. [CrossRef]

67. Labus, K.; Wolanin, K.; Radosiński, Ł. Comparative Study on Enzyme Immobilization Using Natural Hydrogel MatricesExperimental Studies Supported by Molecular Models Analysis. Catalysts 2020, 10, 489. [CrossRef]

68. Kendall, W.F.; Opara, E.C. Polymeric Materials for Perm-Selective Coating of Alginate Microbeads. Methods Mol. Biol. 2017, 1479, 95-109. [CrossRef] [PubMed]

69. Bakry, A.M.; Huang, J.; Zhai, Y.; Huang, Q. Myofibrillar Protein with $\mathrm{k}$ - or $\lambda$-Carrageenans as Novel Shell Materials for Microencapsulation of Tuna Oil through Complex Coacervation. Food Hydrocoll. 2019, 96, 43-53. [CrossRef]

70. Khotimchenko, M.; Tiasto, V.; Kalitnik, A.; Begun, M.; Khotimchenko, R.; Leonteva, E.; Bryukhovetskiy, I.; Khotimchenko, Y. Antitumor Potential of Carrageenans from Marine Red Algae. Carbohydr. Polym. 2020, 246, 116568. [CrossRef]

71. David, S.; Shani Levi, C.; Fahoum, L.; Ungar, Y.; Meyron-Holtz, E.G.; Shpigelman, A. Revisiting the Carrageenan Controversy: Do We Really Understand the Digestive Fate and Safety of Carrageenan in Our Foods? Food Funct. 2018, 9, 1344-1352. [CrossRef] [PubMed]

72. Fauzi, M.A.R.D.; Pudjiastuti, P.; Wibowo, A.C.; Hendradi, E. Preparation, Properties and Potential of Carrageenan-Based Hard Capsules for Replacing Gelatine: A Review. Polymers 2021, 13, 2666. [CrossRef] [PubMed]

73. Geonzon, L.C.; Bacabac, R.G.; Matsukawa, S. Network Structure and Gelation Mechanism of Kappa and Iota Carrageenan Elucidated by Multiple Particle Tracking. Food Hydrocoll. 2019, 92, 173-180. [CrossRef]

74. Zheng, H.; Mao, L.; Cui, M.; Liu, J.; Gao, Y. Development of Food-Grade Bigels Based on k-Carrageenan Hydrogel and Monoglyceride Oleogels as Carriers for $\beta$-Carotene: Roles of Oleogel Fraction. Food Hydrocoll. 2020, 105, 105855. [CrossRef]

75. Silva, R.C.; Trevisan, M.G.; Garcia, J.S. $\beta$-Galactosidase Encapsulated in Carrageenan, Pectin and Carrageenan/Pectin: Comparative Study, Stability and Controlled Release. An. Acad. Bras. Ciências 2020, 92, 20180609. [CrossRef]

76. Malhotra, I.; Basir, S.F. Immobilization of Invertase in Calcium Alginate and Calcium Alginate-Kappa-Carrageenan Beads and Its Application in Bioethanol Production. Prep. Biochem. Biotechnol. 2020, 50, 494-503. [CrossRef]

77. Yamazaki, S.; Mori, T.; Ogino, I.; Mukai, S.R. Flexible Film-Type Catalysts Encapsulating Urease within k-Carrageenan Hydrogel Network. Chem. Eng. J. 2015, 278, 122-128. [CrossRef]

78. Olímpio, F.M.P.; Mendes, A.A.; Trevisan, M.G.; Garcia, J.S. Preparation and Delayed Release Study on Pancreatin Encapsulated into Alginate, Carrageenan and Pectin Hydrogels. J. Braz. Chem. Soc. 2020, 31, 320-330. [CrossRef]

79. Zhang, Z.; Zhang, R.; McClements, D.J. Lactase ( $\beta$-Galactosidase) Encapsulation in Hydrogel Beads with Controlled Internal PH Microenvironments: Impact of Bead Characteristics on Enzyme Activity. Food Hydrocoll. 2017, 67, 85-93. [CrossRef]

80. Desai, P.D.; Dave, A.M.; Devi, S. Entrapment of Lipase into K-Carrageenan Beads and Its Use in Hydrolysis of Olive Oil in Biphasic System. J. Mol. Catalysis. B Enzym. 2004, 31, 143-150. [CrossRef]

81. Wardoyo, F.A.; Hidayah, F.F. Thermal and Reused Stability of Immobilized Lipase in Carrageenan. IOP Conf. Ser. Earth Environ. Sci. 2019, 292, 012028. [CrossRef]

82. Hassan, M.E.; Yang, Q.; Xiao, Z. Covalent Immobilization of Glucoamylase Enzyme onto Chemically Activated Surface of K-Carrageenan. Bull. Natl. Res. Cent. 2019, 43, 1-11. [CrossRef]

83. Caroço, R.F.; Kim, B.; Santacoloma, P.A.; Abildskov, J.; Lee, J.H.; Huusom, J.K. Analysis and Model-Based Optimization of a Pectin Extraction Process. J. Food Eng. 2019, 244, 159-169. [CrossRef]

84. Chan, S.Y.; Choo, W.S.; Young, D.J.; Loh, X.J. Pectin as a Rheology Modifier: Origin, Structure, Commercial Production and Rheology. Carbohydr. Polym. 2017, 161, 118-139. [CrossRef]

85. Cao, L.; Lu, W.; Mata, A.; Nishinari, K.; Fang, Y. Egg-Box Model-Based Gelation of Alginate and Pectin: A Review. Carbohydr. Polym. 2020, 242, 116389. [CrossRef] [PubMed]

86. Picot-Allain, M.C.N.; Ramasawmy, B.; Emmambux, M.N. Extraction, Characterisation, and Application of Pectin from Tropical and Sub-Tropical Fruits: A Review. Food Rev. Int. 2020. [CrossRef]

87. Bilal, M.; Adeel, M.; Rasheed, T.; Zhao, Y.; Iqbal, H.M.N. Emerging Contaminants of High Concern and Their Enzyme-Assisted Biodegradation-A Review. Environ. Int. 2019, 124, 336-353. [CrossRef] [PubMed]

88. Zheng, J.; Chen, J.; Zhang, H.; Wu, D.; Ye, X.; Linardt, R.J.; Chen, S. Gelling Mechanism of RG-I Enriched Citrus Pectin: Role of Arabinose Side-Chains in Cation- and Acid-Induced Gelation. Food Hydrocoll. 2020, 101, 105536. [CrossRef]

89. Costas, L.; Bosio, V.E.; Pandey, A.; Castro, G.R. Effects of Organic Solvents on Immobilized Lipase in Pectin Microspheres. Appl. Biochem. Biotechnol. 2008, 151, 578-586. [CrossRef]

90. Jadhav, S.B.; Singhal, R.S. Co-Conjugation Vis-à-Vis Individual Conjugation of $\alpha$-Amylase and Glucoamylase for Hydrolysis of Starch. Carbohydr. Polym. 2013, 98, 1191-1197. [CrossRef] [PubMed]

91. Bourgeois, S.; Gernet, M.; Pradeau, D.; Andremont, A.; Fattal, E. Evaluation of Critical Formulation Parameters Influencing the Bioactivity of $\beta$-Lactamases Entrapped in Pectin Beads. Int. J. Pharm. 2006, 324, 2-9. [CrossRef] [PubMed] 
92. Muanruksa, P.; Dujjanutat, P.; Kaewkannetra, P. Entrapping Immobilisation of Lipase on Biocomposite Hydrogels toward for Biodiesel Production from Waste Frying Acid Oil. Catalysts 2020, 10, 834. [CrossRef]

93. Sharma, M.; Sangwan, R.S.; Khatkar, B.S.; Singh, S.P. Alginate-Pectin Co-Encapsulation of Dextransucrase and Dextranase for Oligosaccharide Production from Sucrose Feedstocks. Bioprocess. Biosyst. Eng. 2019, 42, 1681-1693. [CrossRef]

94. Satar, R.; Matto, M.; Husain, Q. Studies on Calcium Alginate-Pectin Gel Entrapped Concanavalin A-Bitter Gourd (Momordica Charantia) Peroxidase Complex. J. Sci. Ind. Res. 2008, 67, 609-615.

95. Cruz, M.; Fernandes, K.; Cysneiros, C.; Nassar, R.; Caramori, S. Improvement of Starch Digestion Using $\alpha$-Amylase Entrapped in Pectin-Polyvinyl Alcohol Blend. BioMed Res. Int. 2015, 2015, 145903. [CrossRef]

96. Gómez, L.; Ramírez, H.L.; Neira-Carrillo, A.; Villalonga, R. Polyelectrolyte Complex Formation Mediated Immobilization of Chitosan-Invertase Neoglycoconjugate on Pectin-Coated Chitin. Bioprocess. Biosyst. Eng. 2006, 28, 387-395. [CrossRef]

97. Cargnin, M.A.; Gasparin, B.C.; dos Santos Rosa, D.; Paulino, A.T. Performance of Lactase Encapsulated in Pectin-Based Hydrogels during Lactose Hydrolysis Reactions. LWT 2021, 150, 111863. [CrossRef]

98. Chen, X.; Fu, X.; Huang, L.; Xu, J.; Gao, X. Agar Oligosaccharides: A Review of Preparation, Structures, Bioactivities and Application. Carbohydr. Polym. 2021, 265, 118076. [CrossRef]

99. Imam, H.T.; Marr, P.C.; Marr, A.C. Enzyme Entrapment, Biocatalyst Immobilization without Covalent Attachment. Green Chemistry 2021, 23, 4980-5005. [CrossRef]

100. Nishinari, K.; Fang, Y. Relation between Structure and Rheological/Thermal Properties of Agar. A Mini-Review on the Effect of Alkali Treatment and the Role of Agaropectin. Food Struct. 2017, 13, 24-34. [CrossRef]

101. Sassolas, A.; Hayat, A.; Marty, J.-L. Enzyme Immobilization by Entrapment Within a Gel Network. Methods Mol. Biol. 2013, 1051, 229-239. [CrossRef]

102. Huo, J.; Aguilera-Sigalat, J.; El-Hankari, S.; Bradshaw, D. Magnetic MOF Microreactors for Recyclable Size-Selective Biocatalysis. Chem. Sci. 2015, 6, 1938-1943. [CrossRef]

103. Mahajan, R.; Gupta, V.K.; Sharma, J. Comparison and Suitability of Gel Matrix for Entrapping Higher Content of Enzymes for Commercial Applications. Indian, J. Pharm. Sci. 2010, 72, 223-228. [CrossRef]

104. Prakash, O.; Jaiswal, N. Immobilization of a Thermostable-Amylase on Agarose and Agar Matrices and Its Application in Starch Stain Removal. World Appl. Sci. J. 2011, 13, 572-577.

105. Vieira, M.F.; Vieira, A.M.S.; Zanin, G.M.; Tardioli, P.W.; Mateo, C.; Guisán, J.M. $\beta$-Glucosidase Immobilized and Stabilized on Agarose Matrix Functionalized with Distinct Reactive Groups. J. Mol. Catal. B Enzym. 2011, 69, 47-53. [CrossRef]

106. Zucca, P.; Fernandez-Lafuente, R.; Sanjust, E. Agarose and Its Derivatives as Supports for Enzyme Immobilization. Molecules 2016, 21, 1577. [CrossRef]

107. Ghebremedhin, M.; Seiffert, S.; Vilgis, T.A. Physics of Agarose Fluid Gels: Rheological Properties and Microstructure. Curr. Res. Food Sci. 2021, 4, 436-448. [CrossRef]

108. Russ, N.; Zielbauer, B.I.; Koynov, K.; Vilgis, T.A. Influence of Nongelling Hydrocolloids on the Gelation of Agarose. Biomacromolecules 2013, 14, 4116-4124. [CrossRef]

109. Nordqvist, D.; Vilgis, T.A. Rheological Study of the Gelation Process of Agarose-Based Solutions. Food Biophys. 2011, 6, 450-460. [CrossRef]

110. Vilgis, T.A. Gels: Model Systems for Soft Matter Food Physics. Curr. Opin. Food Sci. 2015, 3, 71-84. [CrossRef]

111. Pedroche, J.; del Mar Yust, M.; Mateo, C.; Fernández-Lafuente, R.; Girón-Calle, J.; Alaiz, M.; Vioque, J.; Guisán, J.M.; Millán, F. Effect of the Support and Experimental Conditions in the Intensity of the Multipoint Covalent Attachment of Proteins on Glyoxyl-Agarose Supports: Correlation between Enzyme-Support Linkages and Thermal Stability. Enzym. Microb. Technol. 2007, 40, 1160-1166. [CrossRef]

112. Kunkel, J.; Asuri, P. Function, Structure, and Stability of Enzymes Confined in Agarose Gels. PLoS ONE 2014, 9, e86785. [CrossRef]

113. Karim, A.; Bibi, Z.; Rehman, H.U.; Aman, A.; Qader, S.A.U.; Rashid, M.H. Single Step Immobilization of CMCase within Agarose Gel Matrix: Kinetics and Thermodynamic Studies. Colloids Surf. B Biointerfaces 2021, 200, 111583. [CrossRef]

114. Silva-Salinas, A.; Rodríguez-Delgado, M.; Gómez-Treviño, J.; López-Chuken, U.; Olvera-Carranza, C.; Blanco-Gámez, E.A. Novel Thermotolerant Amylase from Bacillus Licheniformis Strain LB04: Purification, Characterization and Agar-Agarose. Microorganisms 2021, 9, 1857. [CrossRef]

115. Sattar, H.; Aman, A.; Qader, S.A.U. Agar-Agar Immobilization: An Alternative Approach for the Entrapment of Protease to Improve the Catalytic Efficiency, Thermal Stability and Recycling Efficiency. Int. J. Biol. Macromol. 2018, 111, 917-922. [CrossRef]

116. Mariod, A.A.; Adam, H.F. Review: Gelatin, Source, Extraction and Industrial Applications. Acta Svi. Pol. Technol. Aliment. 2013, 12, 135-147.

117. Sultana, S.; Ali, M.E.; Ahamad, M.N.U. Gelatine, Collagen, and Single Cell Proteins as a Natural and Newly Emerging Food Ingredients. In Preparation and Processing of Religious and Cultural Foods, 1st ed.; Ali, M.E., Nizar, N.N.A., Eds.; Woodhead Publishing: Duxford, UK, 2018; pp. 215-239. [CrossRef]

118. Alipal, J.; Mohd Pu'ad, N.A.S.; Lee, T.C.; Nayan, N.H.M.; Sahari, N.; Basri, H.; Idris, M.I.; Abdullah, H.Z. A Review of Gelatin: Properties, Sources, Process, Applications, and Commercialisation. Mater. Today Proc. 2021, 42, 240-250. [CrossRef]

119. Djabourov, M. Gels. In NMR and MRI of Gels; De Deene, Y., Ed.; The Royal Society of Chemistry: Croydon, UK, 2020; pp. 1-44.

120. Long, H.; Ma, K.; Xiao, Z.; Ren, X.; Yang, G. Preparation and Characteristics of Gelatin Sponges Crosslinked by Microbial Transglutaminase. PeerJ 2017, 5, e3665. [CrossRef] 
121. Savoca, M.P.; Tonoli, E.; Atobatele, A.G.; Verderio, E.A.M. Biocatalysis by Transglutaminases: A Review of Biotechnological Applications. Micromachines 2018, 9, 562. [CrossRef] [PubMed]

122. Labus, K.; Drozd, A.; Trusek-Holownia, A. Preparation and Characterisation of Gelatine Hydrogels Predisposed to Use as Matrices for Effective Immobilisation of Biocatalystst. Chem. Pap. 2016, 70, 523-530. [CrossRef]

123. Salleh, H.M.; Mel, M.; Jami, M.S.; Amid, A.; Bala, M. Optimization of Spray Drying Process Conditions for Recombinant Stem Bromelain. Adv. Environ. Biol. 2014, 8, 696-703.

124. Li, J.; Ma, J.; Jiang, Y.; Jiang, T.; Wang, Y.; Chen, Y.; Liu, S. Immobilizing Enzymes in Regular-Sized Gelatin Microspheres through a Membrane Emulsification Method. J. Mater. Sci. 2016, 51, 6357-6369. [CrossRef]

125. Al-Khafaji, M.A.J.; Ewadh, M.J. Immobilization of Urease in Gelatin Beads for Urea Estimation. Natl. J. Chem. 2009, 33, 131-137.

126. Gan, Z.; Zhang, T.; Liu, Y.; Wu, D. Temperature-Triggered Enzyme Immobilization and Release Based on Cross-Linked Gelatin Nanoparticles. PLoS ONE 2012, 7, e47154. [CrossRef] [PubMed]

127. Sharma, M.; Singh, S.P. Enzyme entrapment approaches and their applications. In Biomass, Biofuels, Biochemicals; Singh, S.P., Pandey, A., Sighania, R.R., Larroche, C., Li, Z., Eds.; Elsevier: Oxford, UK, 2020; pp. 191-216.

128. Mogharabi, M.; Nassiri-Koopaei, N.; Bozorgi-Koushalshahi, M.; Nafissi-Varcheh, N.; Bagherzadeh, G.; Faramarzi, M.A. Immobilization of Laccase in Alginate-Gelatin Mixed Gel and Decolorization of Synthetic Dyes. Bioinorg. Chem. Appl. 2012, 2012, 823830. [CrossRef] [PubMed]

129. Nagatomo, H.; Matsushita, Y.; Sugamoto, K.; Matsui, T. Preparation and Properties of Gelatin-Immobilized $\beta$-Glucosidase from Pyrococcus Furiosus. Biosci. Biotechnol. Biochem. 2005, 69, 128-136. [CrossRef]

130. Jaiswal, N.; Prakash, O.; Talat, M.; Hasan, S.H.; Pandey, R.K. A-Amylase Immobilization on Gelatin: Optimization of Process Variables. J. Genet. Eng. Biotechnol. 2012, 10, 161-167. [CrossRef]

131. Zhang, W.W.; Wang, N.; Zhou, Y.J.; He, T.; Yu, X.Q. Enhancement of Activity and Stability of Lipase by Microemulsion-Based Organogels (MBGs) Immobilization and Application for Synthesis of Arylethyl Acetate. J. Mol. Catal. B Enzym. 2012, 78, 65-71. [CrossRef]

132. Patel, A.R.; Remijn, C.; Cabero, A.I.M.; Heussen, P.C.M.; ten Hoorn, J.W.M.S.; Velikov, K.P. Novel All-Natural Microcapsules from Gelatin and Shellac for Biorelated Applications. Adv. Funct. Mater. 2013, 23, 4710-4718. [CrossRef]

133. D'Souza, A.; Shegokar, R. Polymer: Lipid Hybrid Nanostructures in Cancer Drug Delivery: Successes and Limitations. In Nanoarchitectonics for Smart Delivery and Drug Targeting; Holban, A.M., Grumezescu, A.M., Eds.; William Andrew Publishing: New York, NY, USA, 2016; pp. 431-463. ISBN 978-0-323-47347-7.

134. Sikka, M.P.; Midha, V.K. The role of biopolymers and biodegradable polymeric dressings in managing chronic wounds. In Advanced Textiles for Wound Care; Rajendran, S., Ed.; Woodhead Publishing: Sawston, UK, 2019; pp. $463-488$.

135. Wang, Y.; Feng, C.; Guo, R.; Ma, Y.; Yuan, Y.; Liu, Y. Cellulase Immobilized by Sodium Alginate-Polyethylene Glycol-Chitosan for Hydrolysis Enhancement of Microcrystalline Cellulose. Process. Biochem. 2021, 107, 38-47. [CrossRef]

136. Liao, R.; Pon, J.; Chungyoun, M.; Nance, E. Enzymatic Protection and Biocompatibility Screening of Enzyme-Loaded Polymeric Nanoparticles for Neurotherapeutic Applications. Biomaterials 2020, 257, 120238. [CrossRef]

137. Piao, M.; Zou, D.; Yang, Y.; Ren, X.; Qin, C.; Piao, Y. Multi-Functional Laccase Immobilized Hydrogel Microparticles for Efficient Removal of Bisphenol, A. Materials 2019, 12, 704. [CrossRef] [PubMed]

138. Ataide, J.A.; Geraldes, D.C.; Gérios, E.F.; Bissaco, F.M.; Cefali, L.C.; Oliveira-Nascimento, L.; Mazzola, P.G. Freeze-Dried Chitosan Nanoparticles to Stabilize and Deliver Bromelain. J. Drug Deliv. Sci. Technol. 2021, 61, 102225. [CrossRef]

139. Liu, H.; Nakagawa, K.; Kato, D.I.; Chaudhary, D.; Tadé, M.O. Enzyme Encapsulation in Freeze-Dried Bionanocomposites Prepared from Chitosan and Xanthan Gum Blend. Mater. Chem. Phys. 2011, 129, 488-494. [CrossRef]

140. Steinhilber, D.; Witting, M.; Zhang, X.; Staegemann, M.; Paulus, F.; Friess, W.; Küchler, S.; Haag, R. Surfactant Free Preparation of Biodegradable Dendritic Polyglycerol Nanogels by Inverse Nanoprecipitation for Encapsulation and Release of Pharmaceutical Biomacromolecules. J. Control. Release 2013, 169, 289-295. [CrossRef] [PubMed]

141. Gabrielczyk, J.; Duensing, T.; Buchholz, S.; Schwinges, A.; Jördening, H.J. A Comparative Study on Immobilization of Fructosyltransferase in Biodegradable Polymers by Electrospinning. Appl. Biochem. Biotechnol. 2018, 185, 847-862. [CrossRef]

142. de Souza Simões, L.; Madalena, D.A.; Pinheiro, A.C.; Teixeira, J.A.; Vicente, A.A.; Ramos, Ó.L. Micro- and Nano Bio-Based Delivery Systems for Food Applications: In Vitro Behavior. Adv. Colloid Interface Sci. 2017, 243, 23-45. [CrossRef]

143. Aguiar, J.; Estevinho, B.N.; Santos, L. Microencapsulation of Natural Antioxidants for Food Application-The Specific Case of Coffee Antioxidants-A Review. Trends Food Sci. Technol. 2016, 58, 21-39. [CrossRef]

144. Bobone, S.; Miele, E.; Cerroni, B.; Roversi, D.; Bocedi, A.; Nicolai, E.; di Venere, A.; Placidi, E.; Ricci, G.; Rosato, N.; et al. Liposome-Templated Hydrogel Nanoparticles as Vehicles for Enzyme-Based Therapies. Langmuir 2015, 31, 7572-7580. [CrossRef] [PubMed]

145. Tawfeek, H.M.; Khidr, S.H.; Samy, E.M.; Ahmed, S.M.; Gaskell, E.E.; Hutcheon, G.A. Evaluation of Biodegradable Polyester-CoLactone Microparticles for Protein Delivery. Drug Dev. Ind. Pharm. 2014, 40, 1213-1222. [CrossRef]

146. Galliani, M.; Santi, M.; del Grosso, A.; Cecchettini, A.; Santorelli, F.M.; Hofmann, S.L.; Lu, J.Y.; Angella, L.; Cecchini, M.; Signore, G. Cross-Linked Enzyme Aggregates as Versatile Tool for Enzyme Delivery: Application to Polymeric Nanoparticles. Bioconjugate Chem. 2018, 29, 2225-2231. [CrossRef]

147. Flores-Fernández, G.M.; Griebenow, K. Glycosylation Improves $\alpha$-Chymotrypsin Stability upon Encapsulation in Poly(Lactic-CoGlycolic)Acid Microspheres. Results Pharma Sci. 2012, 2, 46-51. [CrossRef] 
148. Portilla-Arias, J.A.; Camargo, B.; García-Alvarez, M.; de Ilarduya, A.M.; Muñoz-Guerra, S. Nanoparticles Made of Microbial Poly $(\gamma$-Glutamate)s for Encapsulation and Delivery of Drugs and Proteins. J. Biomater. Sci. Polym. Ed. 2009, 20, 1065-1079. [CrossRef] [PubMed]

149. Kim, A.L.; Musin, E.V.; Dubrovskii, A.V.; Tikhonenko, S.A. Effect of Pollyallylamine on Alcoholdehydrogenase Structure and Activity. Polymers 2020, 12, 832. [CrossRef]

150. Dhanjai; Lu, X.; Wu, L.; Chen, J.; Lu, Y. Robust Single-Molecule Enzyme Nanocapsules for Biosensing with Significantly Improved Biosensor Stability. Anal. Chem. 2020, 92, 5830-5837. [CrossRef] [PubMed]

151. Housseiny, M.M.; Aboelmagd, H.I. Nano-Encapsulation of Naringinase Produced by Trichoderma Longibrachiatum ATCC18648 on Thermally Stable Biopolymers for Citrus Juice Debittering. J. Microbiol. 2019, 57, 521-531. [CrossRef]

152. Wagner, I.; Nagy, Z.K.; Vass, P.; Fehér, C.; Barta, Z.; Vigh, T.; Sóti, P.L.; Harasztos, A.H.; Pataki, H.; Balogh, A.; et al. Stable Formulation of Protein-Type Drug in Electrospun Polymeric Fiber Followed by Tableting and Scaling-up Experiments. Polym. Adv. Technol. 2015, 26, 1461-1467. [CrossRef]

153. Yaghoobi, N.; Majidi, R.F.; Faramarzi, M.A.; Baharifar, H.; Amani, A. Preparation, Optimization and Activity Evaluation of PLGA/Streptokinase Nanoparticles Using Electrospray. Adv. Pharm. Bull. 2017, 7, 131-139. [CrossRef]

154. Morales-Cruz, M.; Flores-Fernández, G.M.; Morales-Cruz, M.; Orellano, E.A.; Rodriguez-Martinez, J.A.; Ruiz, M.; Griebenow, K. Two-Step Nanoprecipitation for the Production of Protein-Loaded PLGA Nanospheres. Results Pharma Sci. 2012, 2, 79-85. [CrossRef] [PubMed]

155. Lindhoud, S.; de Vries, R.; Norde, W.; Stuart, M.A.C. Structure and Stability of Complex Coacervate Core Micelles with Lysozyme. Biomacromolecules 2007, 8, 2219-2227. [CrossRef] [PubMed]

156. Babich, O.; Dyshlyuk, L.; Prosekov, A.; Noskova, S.; Ivina, O.; Pavsky, V.; Ivanova, S.; Bulgakova, O. Study of the Potential of the Capsule Shell Based on Natural Polysaccharides in Targeted Delivery of the L-Phenylalanine Ammonia-Lyase Enzyme Preparation. Pharmaceuticals 2020, 13, 63. [CrossRef]

157. Estevinho, B.N.; Damas, A.M.; Martins, P.; Rocha, F. Study of the Inhibition Effect on the Microencapsulated Enzyme $\beta$ Galactosidase. Environ. Eng. Manag. J. 2012, 11, 1923-1930. [CrossRef]

158. Chong-Cerda, R.; Levin, L.; Castro-Rios, R.; Hérnandez-Luna, C.E.; González-Horta, A.; Gutiérrez-Soto, G.; Chávez-Montes, A Nanoencapsulated Laccases Obtained by Double-Emulsion Technique. Effects on EnzymeActivity PH-Dependence and Stability. Catalysts 2020, 10, 1085. [CrossRef]

159. Tawfeek, H.M.; Evans, A.R.; Iftikhar, A.; Mohammed, A.R.; Shabir, A.; Somavarapu, S.; Hutcheon, G.A.; Saleem, I.Y. Dry Powder Inhalation of Macromolecules Using Novel PEG-Co-Polyester Microparticle Carriers. Int. J. Pharm. 2013, 441, 611-619. [CrossRef]

160. Larrañaga, A.; Isa, I.L.M.; Patil, V.; Thamboo, S.; Lomora, M.; Fernández-Yague, M.A.; Sarasua, J.R.; Palivan, C.G.; Pandit, A. Antioxidant Functionalized Polymer Capsules to Prevent Oxidative Stress. Acta Biomater. 2018, 67, 21-31. [CrossRef]

161. Karamitros, C.S.; Yashchenok, A.M.; Möhwald, H.; Skirtach, A.G.; Konrad, M. Preserving Catalytic Activity and Enhancing Biochemical Stability of the Therapeutic Enzyme Asparaginase by Biocompatible Multilayered Polyelectrolyte Microcapsules. Biomacromolecules 2013, 14, 4398-4406. [CrossRef] [PubMed]

162. Lino, P.R.; Leandro, J.; Amaro, M.; Gonçalves, L.M.D.; Leandro, P.; Almeida, A.J. In Silico and in Vitro Tailoring of a Chitosan Nanoformulation of a Human Metabolic Enzyme. Pharmaceutics 2021, 13, 329. [CrossRef]

163. Mahmoud, K.F.; Abo-Elmagd, H.I.; Housseiny, M.M. Micro- and Nano-Capsulated Fungal Pectinase with Outstanding Capabilities of Eliminating Turbidity in Freshly Produced Juice. Food Sci. Technol. Int. 2018, 24, 330-340. [CrossRef] [PubMed]

164. Patil, J.S.; Kamalapur, M.V.; Marapur, S.C.; Kadam, D. Ionotropic Gelation And Polyelectrolyte Complexation: The Novel Techniques To Design Hydrogel Particulate Sustained, Modulated Drug Delivery System: A Review. Dig. J. Nanomater. Biostructures 2010, 5, 241-248.

165. Comunian, T.A.; Favaro-Trindade, C.S. Microencapsulation Using Biopolymers as an Alternative to Produce Food Enhanced with Phytosterols and Omega-3 Fatty Acids: A Review. Food Hydrocoll. 2016, 61, 442-457. [CrossRef]

166. Bahreini, E.; Aghaiypour, K.; Abbasalipourkabir, R.; Mokarram, A.R.; Goodarzi, M.T.; Saidijam, M. Preparation and Nanoencapsulation of L-Asparaginase II in Chitosan-Tripolyphosphate Nanoparticles and in Vitro Release Study. Nanoscale Res. Lett. 2014, 9, 1-13. [CrossRef]

167. Vimal, A.; Kumar, A. Antimicrobial Potency Evaluation of Free and Immobilized L-Asparaginase Using Chitosan Nanoparticles. J. Drug Deliv. Sci. Technol. 2021, 61, 102231. [CrossRef]

168. Bilal, M.; Iqbal, H.M.N.; Hu, H.; Wang, W.; Zhang, X. Enhanced Bio-Catalytic Performance and Dye Degradation Potential of Chitosan-Encapsulated Horseradish Peroxidase in a Packed Bed Reactor System. Sci. Total. Environ. 2017, 575, 1352-1360. [CrossRef]

169. Jaiswal, N.; Pandey, V.P.; Dwivedi, U.N. Immobilization of Papaya Laccase in Chitosan Led to Improved Multipronged Stability and Dye Discoloration. Int. J. Biol. Macromol. 2016, 86, 288-295. [CrossRef] [PubMed]

170. Gharsallaoui, A.; Roudaut, G.; Chambin, O.; Voilley, A.; Saurel, R. Applications of Spray-Drying in Microencapsulation of Food Ingredients: An Overview. Food Res. Int. 2007, 40, 1107-1121. [CrossRef]

171. Arpagaus, C.; Collenberg, A.; Rütti, D.; Assadpour, E.; Jafari, S.M. Nano Spray Drying for Encapsulation of Pharmaceuticals. Int. J. Pharm. 2018, 546, 194-214. [CrossRef] [PubMed]

172. Cal, K.; Sollohub, K. Spray Drying Technique. I: Hardware and Process Parameters. J. Pharm. Sci. 2010, 99, 575-586. [CrossRef] [PubMed] 
173. Samborska, K.; Witrowa-Rajchert, D.; Gonçalves, A. Spray-Drying of $\alpha$-Amylase-The Effect of Process Variables on the Enzyme Inactivation. Dry. Technol. 2005, 23, 941-953. [CrossRef]

174. Shishir, M.R.I.; Xie, L.; Sun, C.; Zheng, X.; Chen, W. Advances in Micro and Nano-Encapsulation of Bioactive Compounds Using Biopolymer and Lipid-Based Transporters. Trends Food Sci. Technol. 2018, 78, 34-60. [CrossRef]

175. Vishali, D.A.; Monisha, J.; Sivakamasundari, S.K.; Moses, J.A.; Anandharamakrishnan, C. Spray freeze drying: Emerging applications in drug delivery. J. Control. Release 2019, 300, 93-101. [CrossRef]

176. Martínez Rivas, C.J.; Tarhini, M.; Badri, W.; Miladi, K.; Greige-Gerges, H.; Nazari, Q.A.; Galindo Rodríguez, S.A.; Román, R.Á.; Fessi, H.; Elaissari, A. Nanoprecipitation Process: From Encapsulation to Drug Delivery. Int. J. Pharm. 2017, 532, 66-81. [CrossRef] [PubMed]

177. Fessi, H.; Puisieux, F.; Devissaguet, J.P.; Ammoury, N.; Benita, S. Nanocapsule Formation by Interfacial Polymer Deposition Following Solvent Displacement. Int. J. Pharm. 1989, 55, R1-R4. [CrossRef]

178. Echegoyen, Y.; Fabra, M.J.; Castro-Mayorga, J.L.; Cherpinski, A.; Lagaron, J.M. High Throughput Electro-Hydrodynamic Processing in Food Encapsulation and Food Packaging Applications: Viewpoint. Trends Food Sci. Technol. 2017, 60, 71-79. [CrossRef]

179. Mendes, A.C.; Stephansen, K.; Chronakis, I.S. Electrospinning of Food Proteins and Polysaccharides. Food Hydrocoll. 2017, 68, 53-68. [CrossRef]

180. Luraghi, A.; Peri, F.; Moroni, L. Electrospinning for Drug Delivery Applications: A Review. J. Control. Release 2021, 334, 463-484. [CrossRef]

181. Fredenberg, S.; Wahlgren, M.; Reslow, M.; Axelsson, A. The Mechanisms of Drug Release in Poly(Lactic-Co-Glycolic Acid)-Based Drug Delivery Systems-A Review. Int. J. Pharm. 2011, 415, 34-52. [CrossRef] [PubMed]

182. Boostani, S.; Jafari, S.M. A Comprehensive Review on the Controlled Release of Encapsulated Food Ingredients; Fundamental Concepts to Design and Applications. Trends Food Sci. Technol. 2021, 109, 303-321. [CrossRef]

183. Mora-Huertas, C.E.; Fessi, H.; Elaissari, A. Polymer-Based Nanocapsules for Drug Delivery. Int. J. Pharm. 2010, $385,113-142$. [CrossRef] [PubMed]

184. Miladi, K.; Sfar, S.; Fessi, H.; Elaissari, A. Nanoprecipitation Process: From Particle Preparation to In Vivo Applications. In Polymer Nanoparticles for Nanomedicines; Vauthier, C., Ponchel, G., Eds.; Springer International Publishing: Gewerbestrasse, Switzerland, 2016; pp. 17-53.

185. Spink, C.H. Differential Scanning Calorimetry. Methods Cell Biol. 2008, 84, 115-141. [PubMed]

186. Kita, K.; Dittrich, C. Drug Delivery Vehicles with Improved Encapsulation Efficiency: Taking Advantage of Specific Drug-Carrier Interactions. Expert Opin. Drug Deliv. 2011, 8, 329-342. [CrossRef] [PubMed]

187. Eghbal, N.; Choudhary, R. Complex Coacervation: Encapsulation and Controlled Release of Active Agents in Food Systems. LWT 2018, 90, 254-264. [CrossRef]

188. Sharma, N.; Madan, P.; Lin, S. Effect of Process and Formulation Variables on the Preparation of Parenteral Paclitaxel-Loaded Biodegradable Polymeric Nanoparticles: A Co-Surfactant Study. Asian J. Pharm. Sci. 2016, 11, 404-416. [CrossRef]

189. Jyothi, N.; Venkata, N.; Jyothi, N.; Prasanna, P.M.; Narayan Sakarkar, S.; Surya Prabha, K.; Ramaiah, P.S.; Srawan, G.Y. Microencapsulation Techniques, Factors Influencing Encapsulation Efficiency. Artic. J. Microencapsul. 2010, 27, 187-197. [CrossRef] [PubMed]

190. Srikar, G.; Rani, A.P. Study on Influence of Polymer and Surfactant on in Vitro Performance of Biodegradable Aqueous-Core Nanocapsules of Tenofovirdisoproxil Fumarate by Response Surface Methodology. Braz. J. Pharm. Sci. 2019, 55, e18736. [CrossRef]

191. Shoba, E.; Lakra, R.; Kiran, M.S.; Korrapati, P.S. Design and Development of Papain-Urea Loaded PVA Nanofibers for Wound Debridement. RSC Adv. 2014, 4, 60209-60215. [CrossRef]

192. Mak, W.C.; Cheung, K.Y.; Trau, D. Diffusion Controlled and Temperature Stable Microcapsule Reaction Compartments for High-Throughput Microcapsule-PCR. Adv. Funct. Mater. 2008, 18, 2930-2937. [CrossRef]

193. Price, A.D.; Zelikin, A.N.; Wark, K.L.; Caruso, F. A Biomolecular "Ship-in-a-bottle": Continuous RNA Synthesis Within Hollow Polymer Hydrogel Assemblies. Adv. Mater. 2010, 22, 720-723. [CrossRef] [PubMed]

194. Pan, H.M.; Yu, H.; Guigas, G.; Fery, A.; Weiss, M.; Patzel, V.; Trau, D. Engineering and Design of Polymeric Shells: Inwards Interweaving Polymers as Multilayer Nanofilm, Immobilization Matrix, or Chromatography Resins. ACS Appl. Mater. Interfaces 2017, 9, 5447-5456. [CrossRef] 